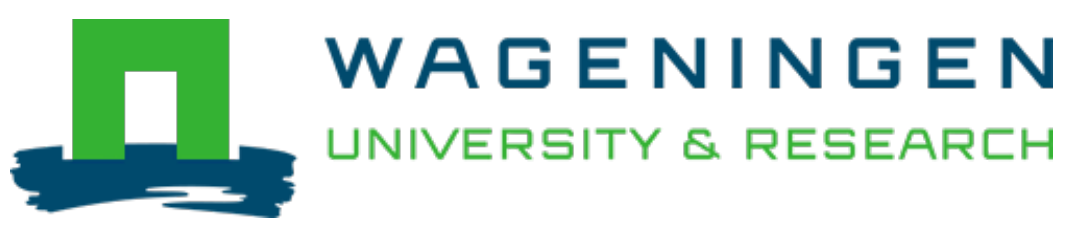

\title{
Designing intercrops for high yield, yield stability and efficient use of resources: Are there principles?
}

\author{
Advances in Agronomy \\ Stomph, Tjeerd Jan; Dordas, Christos; Baranger, Alain; Rijk, Joshua; Dong, Bei et al \\ https://doi.org/10.1016/bs.agron.2019.10.002
}

This publication is made publicly available in the institutional repository of Wageningen University and Research, under the terms of article $25 \mathrm{fa}$ of the Dutch Copyright Act, also known as the Amendment Taverne. This has been done with explicit consent by the author.

Article 25 fa states that the author of a short scientific work funded either wholly or partially by Dutch public funds is entitled to make that work publicly available for no consideration following a reasonable period of time after the work was first published, provided that clear reference is made to the source of the first publication of the work.

This publication is distributed under The Association of Universities in the Netherlands (VSNU) 'Article $25 \mathrm{fa}$ implementation' project. In this project research outputs of researchers employed by Dutch Universities that comply with the legal requirements of Article $25 \mathrm{fa}$ of the Dutch Copyright Act are distributed online and free of cost or other barriers in institutional repositories. Research outputs are distributed six months after their first online publication in the original published version and with proper attribution to the source of the original publication.

You are permitted to download and use the publication for personal purposes. All rights remain with the author(s) and / or copyright owner(s) of this work. Any use of the publication or parts of it other than authorised under article $25 \mathrm{fa}$ of the Dutch Copyright act is prohibited. Wageningen University \& Research and the author(s) of this publication shall not be held responsible or liable for any damages resulting from your (re)use of this publication.

For questions regarding the public availability of this publication please contact openscience.library@wur.nl 


\title{
Designing intercrops for high yield, yield stability and efficient use of resources: Are there principles?
}

\author{
TjeerdJan Stomph $^{\mathrm{a}, *}$, Christos Dordas ${ }^{\mathrm{b}}$, Alain Baranger ${ }^{\mathrm{c}}$, \\ Joshua de Rijka , Bei Dong ${ }^{a}$, Jochem Evers ${ }^{a}$, Chunfeng Gu ${ }^{a}$, Long Li ${ }^{e}$, \\ Johan Simon ${ }^{\mathrm{a}}$, Erik Steen Jensen ${ }^{\mathrm{f}}, \mathrm{Qi}$ Wang $^{\mathrm{a}}$, Yuyun Wang ${ }^{\mathrm{g}}$, \\ Zishen Wang ${ }^{a}$, Huasen $\mathrm{Xu}^{\mathrm{e}}$, Chaochun Zhang ${ }^{\mathrm{e}}$, Lizhen Zhang ${ }^{\mathrm{e}}$, \\ Wei-Ping Zhang ${ }^{\mathrm{e}}$, Laurent Bedoussac ${ }^{\mathrm{d}}$, Wopke van der Werf ${ }^{\mathrm{a}}$ \\ ${ }^{a}$ Wageningen University, Centre for Crop Systems Analysis, Wageningen, The Netherlands \\ ${ }^{\mathrm{b}}$ Aristotle University of Thessaloniki, School of Agriculture, Laboratory of Agronomy, Thessaloniki, Greece \\ ${ }^{c}$ INRA, UMR Institute for Genetics, Environment and Plant Protection, Le Rheu cedex, France \\ dAGIR, Université de Toulouse, INRA, ENSFEA, Castanet-Tolosan, France \\ ${ }^{\mathrm{e}}$ China Agricultural University, College of Resources and Environmental Sciences, Beijing, China \\ ${ }^{\mathrm{f}}$ Swedish University of Agricultural Sciences, Department of Biosystems and Technology, Alnarp, Sweden \\ ${ }^{\mathrm{g}}$ Yunnan Agricultural University, Kunming, Yunnan, China \\ ${ }^{*}$ Corresponding author: e-mail address: tjeerdjan.stomph@wur.nl
}

\section{Contents}

1. Introduction 2

1.1 Resource use efficiency in intercrops 4

1.2 Expressing intercrop yield advantage 6

2. Resource acquisition and conversion efficiencies 8

2.1 Light 9

2.2 Water 11

2.3 Nutrients 15

$\begin{array}{ll}2.4 \text { Interactions between resources } & 19\end{array}$

3. Long-term effects on soil quality 20

$\begin{array}{ll}3.1 \text { Carbon } 20 & 20\end{array}$

$\begin{array}{ll}3.2 \text { Nitrogen } & 21\end{array}$

3.3 Phosphorus and potassium 22

4. Climate change, yield stability and resilience to stress 23

4.1 Yield stability 23

4.2 Abiotic stresses: Coping with future climates 25

5. Biotic stress 26

5.1 Disease control by intercropping 27

5.2 Intercropping effects on diseases: An analysis based on vote counting 28

$\begin{array}{ll}5.3 \text { Intercropping effects on pests } & 29\end{array}$ 
5.4 Effects of intercropping on weeds: An analysis based on vote counting 31

6. Product quality 33

6.1 Cereal and legume grain protein concentration 33

6.2 Cereal and legume grain micronutrient concentration 34

7. Synthesis and outlook 35

$\begin{array}{lll}\text { 7.1 Further work is needed in many domains } & 39\end{array}$

$\begin{array}{ll}\text { Acknowledgments } & 40\end{array}$

$\begin{array}{ll}\text { References } & 41\end{array}$

\begin{abstract}
Intercropping is the simultaneous cultivation of plant species in the same field for a considerable proportion of their growing periods. Interest in intercropping for sustainable agriculture is on the rise and the number of scientific studies on intercropping is strongly increasing. Here we assess the current status of knowledge on factors that determine yield, yield stability and resource use efficiency of intercropping as compared to sole cropping. Distinguishing resource use into acquisition and conversion shows that intercrops are mainly improving acquisition rather than conversion efficiency. We also make an attempt to quantify the importance of reduced biotic stresses through pests, diseases, and weeds. We particularly focus on blank spots in the knowledge and possible bias in existing literature and ask which research approaches are needed to advance the field and pave the way for a wider usage of intercropping in modern sustainable agriculture.
\end{abstract}

\title{
1. Introduction
}

Intercropping is the simultaneous cultivation of different plant species in the same field for at least part of their growing season. Interest in intercropping for sustainable agriculture is on the rise and the number of scientific studies on intercropping is strongly increasing (Fig. 1). In the past decade a number of qualitative reviews have been published (Bedoussac et al., 2015; Boudreau, 2013; Brooker et al., 2008, 2015; Letourneau et al., 2011; Lithourgidis et al., 2011; Xue et al., 2016), as well as some systematic reviews (Martin-Guay et al., 2018; Pelzer et al., 2014; Raseduzzaman and Jensen, 2017; Valkama et al., 2015; Yu et al., 2015, 2016a,b) all focusing on specific aspects of intercropping.

Analysis of productivity and resource use efficiency in intercropping needs a conceptual framework. For this chapter, we use the classical delineation between growth determining, growth limiting and growth reducing factors (van Ittersum and Rabbinge, 1997; Fig. 2). Growth determining factors determine the potential level of production. They include genetic 


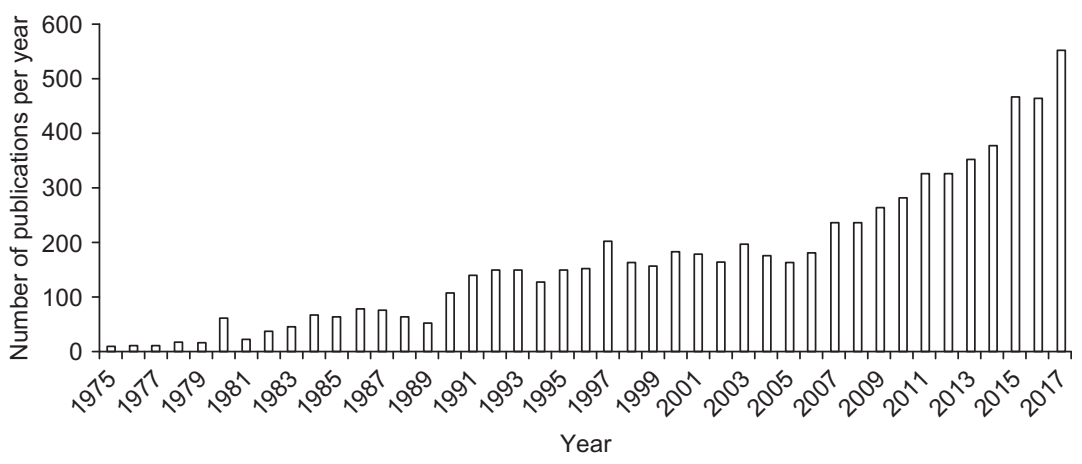

Fig. 1 Number of publications per year between 1975 and 2017 focusing on intercropping found through a search on Web of Science using "Indexes $=\mathrm{SCl}$ EXPANDED, SSCl, A\&HCl, ESCl" and as search string "(Topic=(intercrop* OR "mixed crop*" OR "crop mix*" OR "mixed cultivation*" OR polyculture) NOT Topic $=$ (tree* OR perennial)) AND DOCUMENT TYPES: (Article)."

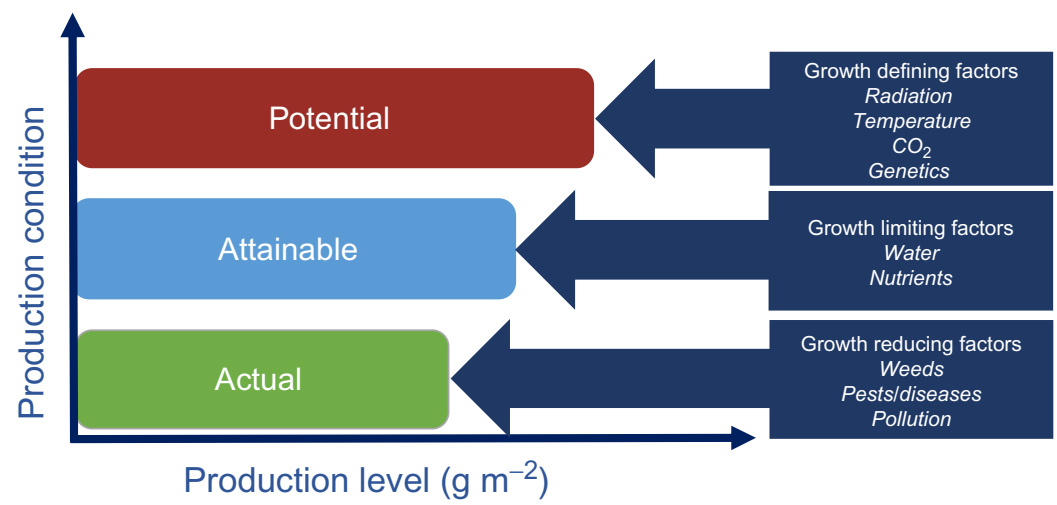

Fig. 2 The relationship among potential, attainable and actual production levels and the growth defining, growth limiting and growth reducing factors. Modified from van Ittersum, M.K., Rabbinge, R., 1997. Concepts in production ecology for analysis and quantification of agricultural input-output combinations. Field Crop Res. 52, 197-208.

traits of the crop species and the variety (e.g., response to temperature, $\mathrm{C}_{3}$ or $\mathrm{C}_{4}$ photosynthesis) and the growth factors temperature, incoming radiation, and $\mathrm{CO}_{2}$ concentration. These plant and environmental traits determine to a large extent the potential amount of energy that a crop can accumulate in dry matter over the course of its growth duration and therefore the yield. The resulting production is called potential growth (van Ittersum and Rabbinge, 1997). Sufficient water and nutrients are needed to allow the plant to achieve its potential photosynthesis and carbon accumulation. Water is needed as a carrier material in the plant, to cool and to maintain 
gas exchange and cell turgor, while nutrients (N, P, K, and other macro- and micro-nutrients) are essential biochemical building blocks of the plant. The yield level when available water and/or nutrients fall short of those needed for potential production is called the water- or nutrient-limited yield, or simply, the attainable yield. Finally, growth reducing factors, i.e., pests, diseases and weeds, affect growth rate, biomass accumulation and yield. Their growth reducing effects contribute negatively to the actual yields observed under field conditions. Beyond the field level further reducing factors can be proposed (e.g., Viguier et al., 2018) but these are beyond the scope of this review.

Intercropping can affect potential, attainable as well as actual yield. Potential yield can be changed through an extension of the growing season, resulting in greater light capture, as in relay intercropping (Zhang et al., 2008). Attainable yield can be improved by complementarity between species in the timing of water demand (in relay intercropping), the depth of water extraction, different modes of nitrogen acquisition (with legumes fixing nitrogen from air) or recirculation of nitrogen in the soil-plant system during the growing season in relay intercrops (Cong et al., 2014). Actual yield can be increased by enhanced control of pest infestation and disease contamination and development, for instance due to dilution of the host or other mechanisms (Boudreau, 2013), and differences between species, or varieties within species, in their susceptibility to adverse biotic or abiotic conditions can result in compensation responses that limit yield reductions in intercrops as compared to the (average) effects occurring in sole crops.

The production situation has therefore critical consequences for the possible effects of intercropping on productivity, and the mechanisms by which intercropping will do this. Different intercropping designs are expected to be functional in production situations that are characterized as potential, water or nutrient-limited (nitrogen, phosphorus, and/or other macro or micronutrients), or vulnerable to pest infestations, disease contaminations, weed invasions or climatic extremes.

\subsection{Resource use efficiency in intercrops}

When assessing resource use efficiency in intercrops, it is essential to distinguish between acquisition efficiency (i.e., the fraction of the available resource that is captured or net taken up) and conversion efficiency (the ratio between biomass or yield and the amount of acquired resource). Resource use efficiency is the product of the two: 


$\begin{gathered}\text { use efficiency } \\ \mathrm{kg} \text { yield or biomass per } \\ \text { unit resource available }\end{gathered}=\begin{gathered}\text { acquisition efficiency } \\ \text { resource captured per } \\ \text { unit resource available }\end{gathered} \times \begin{gathered}\text { conversion efficiency } \\ \text { yield or biomass per } \\ \text { unit resource captured }\end{gathered}$

Three quadrant diagrams have been introduced to assess in a single figure the effect of management on productivity, acquisition and conversion in sole crops (van Keulen, 1982; Fig. 3). In these figures, the bottom right quadrant (I) shows the relationship between the resource applied and the resource acquired. The top right quadrant (II) shows the relationship between the resource acquired and the biomass or yield. The top left quadrant (III), finally, shows the resultant relationship between the resource applied and the biomass or yield. Three quadrant diagrams have so far not been used to study the performance of intercropping, and in sole crops, the use of three quadrant diagrams has been limited to the analysis of nutrient use efficiency. Nevertheless, a similar distinction between acquisition and conversion can be made for light and for water, resulting in metrics for light acquisition efficiency (photosynthetic active radiation (PAR) absorbed per unit PAR available during a growing season) and light conversion

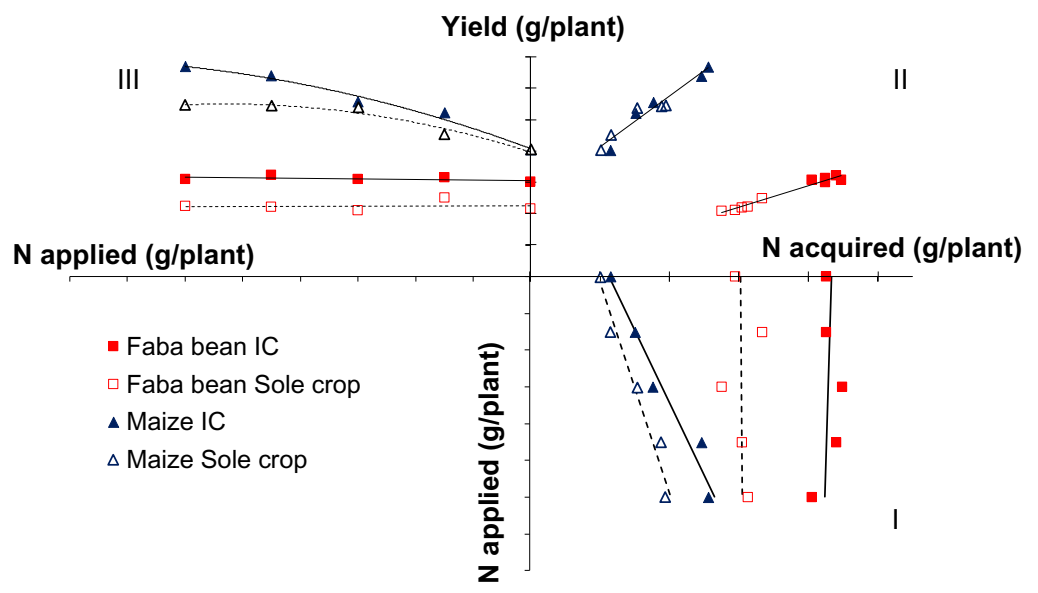

Fig. 3 The "three quadrant diagram" of nitrogen response (after van Keulen, 1982), applied to actual intercrop data for nitrogen from Li et al. (2009) averaged over two seasons in a replacement strip intercrop of maize and faba bean. Quadrant III is the standard agronomic or yield response and this is explained from quadrant I, i.e., the root and soil processes leading to nitrogen acquisition and quadrant II, i.e., the physiological processes leading to nitrogen conversion into biomass and yield. 
efficiency (biomass or yield per unit of PAR absorbed; usually called light use efficiency), for water acquisition efficiency (water acquired per unit water available) and for water conversion efficiency (biomass or yield per unit of water acquired). In essence, high yield and high efficiency are driven by exploiting the full length of the growing season with full soil cover, active root functioning and thorough soil exploration, such that all the available light, water and nutrient resources are used, and losses minimized.

In three quadrant diagrams for nutrients, quantities plotted are application rate of the nutrient, the amount of the nutrient acquired, and the resulting biomass or yield produced. With the exception of nitrogen for legumes, the slope of the relationship between nutrient applied and nutrient acquired (quadrant I) is the acquisition efficiency. The point where the line for non-legumes through the data crosses the acquisition axis is the nutrient amount delivered by the soil when no nutrients are applied. The acquisition efficiency can be defined as a marginal efficiency (tangent line to the curve) or as the overall efficiency (slope of the line connecting a point on the curve to the origin or to the intercept indicating the nutrient amount delivered by the soil). In studies with nutrients in sole crops, the relationship between resource given and nutrient acquired is often linear over a wide range of application levels and the slope (nutrient acquired per unit supplied) is called the recovery. The relationship between the acquired nutrient amount and the biomass or production (quadrant II) characterizes the conversion efficiency. A greater conversion efficiency means that for the same resource acquired, more biomass or yield is produced. Typically, this efficiency is higher for $\mathrm{C}_{4}$ than for $\mathrm{C}_{3}$ species as also shown in Fig. 3. For nutrients, the mass concentration in the plant biomass is the inverse of this conversion efficiency. A few studies have used acquisition efficiency and conversion efficiency to analyze the basis of high land use efficiency (LER, see below) in intercropping (Morris and Garrity, 1993a,b), but the concepts outlined above have, to our knowledge, never been used systematically to assess the relative role of acquisition and conversion efficiency for light, water and nutrients.

\subsection{Expressing intercrop yield advantage}

A recurring difficulty in the analysis of resource use efficiency in intercropping is the question how to put the yields of different component species on a common denominator. The by far most used concept in this 
respect is the land equivalent ratio (LER). It represents the land area needed to produce the yields obtained in a unit area of intercrop using sole crops (Mead and Willey, 1980). The LER is calculated as:

$$
L E R=\frac{Y_{1}}{M_{1}}+\frac{Y_{2}}{M_{2}}=p L E R_{1}+p L E R_{2}
$$

where $Y_{1}$ and $Y_{2}$ are the intercrop yields of species 1 and 2, respectively, while $M_{1}$ and $M_{2}$ are the sole crop yields, and $p L E R_{1,2}$ are the respective relative yields or partial land equivalent ratios of the two intercropped species. An LER above one means a higher land use efficiency of an intercrop compared to a sole crop. A similar concept can be used to characterize the amount of water needed to produce the yield obtained with a unit water in intercropping, using sole crops (Mao et al., 2012). The water equivalent ratio (WER) is calculated as:

$$
W E R=p L E R_{1} \times \frac{W U_{1}}{W U_{I C}}+p L E R_{2} \times \frac{W U_{2}}{W U_{I C}}
$$

where $W U_{1}$ and $W U_{2}$ are the water use (evaporation and transpiration) by the sole crops while $W U_{\text {IC }}$ is the water use by the intercrop. Mao et al. (2012) present a derivation and rationale for the metric. Using similar principles, metrics could be developed for nutrient use efficiencies of, e.g., $\mathrm{N}$ or $\mathrm{P}$. Many metrics have been suggested and limitations to their interpretation have been discussed (Bedoussac and Justes, 2011; Connolly et al., 2001). For this paper, especially those metrics are relevant that characterize resource use efficiency at the whole crop level and that may be used to diagnose efficient vs inefficient intercrop designs in a given agro-climatic context. Here, design is meant to encompass the choice of species and variety traits, sowing dates, intercropping pattern (mixed, rows, strips, strip width), type and amount of fertilizer and use of biocides.

There is an urgent need for intercropping as a research area to (i) use agreed metrics to characterize whole system level performance as compared to sole crops (as the measures above do as long as used appropriately; Bedoussac and Justes, 2011; Mao et al., 2012); (ii) develop predictive models to identify system traits and plant traits that work together to maximize resource use efficiencies, to mitigate losses of nutrients and environmental side effects of those spills, and obtain high stable yields at lower levels of input; (iii) make use of the ability of intercropping to reduce incidence, severity and the impacts of pests, diseases and weeds, and thereby reduce 
the need for insurance use of biocides in agriculture. This requires increases in the resilience and robustness of cropping systems, which is where intercrops can help (Raseduzzaman and Jensen, 2017).

This review aims to describe the state of knowledge on intercropping in terms of resource acquisition, conversion efficiency, productivity and product quality and the key processes and system characteristics underlying these. It summarizes key references and points out where knowledge is missing. It aims to put different mechanisms for increased resource acquisition and conversion efficiency in perspective in terms of the production situation and the role of growth determining, growth limiting and growth reducing factors. It summarizes key knowledge on nutrient cycling and the effect of intercropping on product quality as a result of relaxation of competition for nutrients in cereal/legume systems. Finally, it provides a semi-quantitative synthesis of the effects of intercropping on pest and disease control, and the suppression of weeds. The ultimate goal of this synthesis is to derive design principles for intercrops that have high yield, yield stability and high resource use efficiency. Where this is not possible or difficult, we outline the needs for future research.

\section{Resource acquisition and conversion efficiencies}

One of the most important advantages of intercropping is the more efficient acquisition and/or conversion of the available resources leading to an increased productivity compared with the sole crops that constitute the intercrop (Andersen et al., 2007; Bedoussac et al., 2015; Brooker et al., 2015; Dhima et al., 2007; Hauggaard-Nielsen et al., 2001b, 2003; Li et al., 1999, 2014; Ofosu-Anim and Limbani, 2007; Szumigalski and Van Acker, 2006). Yield advantage occurs because growth resources, such as light, water, and nutrients are more completely acquired and/or converted into biomass by the intercrop than by the component sole crops. Normally, complementary acquisition of resources occurs when the component species of an intercrop acquire qualitatively different resources or acquire the same resources at different places or at different times (Tofinga et al., 1993). In ecological terms, resource complementarity means a reduced niche overlap and competition between species in an intercrop, which permits the species to acquire a greater range and quantity of resources in intercrops than they can in sole stands. Selection of crops that differ in resource acquisition in time or space is essential to reduce competition and enable complementarity. Maximizing complementarity also needs consideration of when to plant, at what density, and in what arrangement. 


\subsection{Light}

In field crops, there is often a linear relationship between cumulative intercepted PAR and accumulated biomass. The slope of this relationship is usually called light use efficiency or radiation use efficiency (Gallagher and Biscoe, 1978; Russell et al., 1989), but for consistency with terminology for water and nutrients, we will further use the term light conversion efficiency. Under potential growing conditions, yield advantages in intercropping could be achieved by increases in the acquisition and/or the conversion efficiency of solar radiation (Keating and Carberry, 1993).

\subsubsection{Light acquisition is often enhanced in intercropping}

Light acquisition can be enhanced by combining species that cover the soil and use radiation during different parts of the growing season (Awal et al., 2006; Mahallati et al., 2015; Wang et al., 2015a). For example, strip-relay intercrops acquire more light due to a longer period of light acquisition in comparison to sole crops (Gou et al., 2017a; Keating and Carberry, 1993; Lithourgidis et al., 2011; Wang et al., 2015a; Zhang et al., 2008; Zhu et al., 2015;). Such intercrops may also acquire more light than sole crops due to spatial complementary for light acquisition. This can occur if intercropped species differ in plant architectural development and plastically respond to local high light availability (Zhu et al., 2015). The potential for complementarity in light acquisition is affected by row spacing and intercrop arrangement. For instance, the width of wheat and cotton strips, the density within the row and the fraction of land area per plant affect total light acquisition as well as the distribution of acquired light over both component crops (Mao et al., 2016; Zhang et al., 2007, 2008). In strip intercrops, the complementarity and competition between species is usually quite conspicuous as a results of so-called "border row effects," where the border rows either have more yield and biomass as a result of relaxed competition from their neighbor, or - alternatively - less because of enhanced competition (Li et al., 2001; van Oort et al., 2020; Zhang et al., 2007, 2008; Zhu et al., 2016).

\subsubsection{Light conversion efficiency}

Effects of intercropping on light conversion efficiency vary substantially across studies. Most studies report on combinations of tall $\mathrm{C}_{4}$ cereals and short $\mathrm{C}_{3}$ legumes. The general picture is that maize (Awal et al., 2006; Gao et al., 2010), sorghum (Matthews et al., 1991) or millet (Marshall and Willey, 1983) have similar light conversion efficiencies in 
sole crops and intercrops while their increased productivity in intercrops is related to an increased interception of light at the expense of the understorey legumes. The legumes in these systems, groundnut (Awal et al., 2006; Marshall and Willey, 1983; Matthews et al., 1991) and soybean (Gao et al., 2010), are mostly reported to have lower yields but an increased light conversion efficiency while they intercept much less light in the intercrop than in the sole crop. This higher light conversion efficiency at lower light intensity could be a simple consequence of the curvilinear shape of the photosynthesis light response curve; however, the presented data do not allow to confirm this hypothesis.

An intercrop of $\mathrm{C}_{3}$ and $\mathrm{C}_{4}$ species may result in both spatio-temporal and functional complementarity, as $\mathrm{C}_{4}$ crops are taller than $\mathrm{C}_{3}$ crops and $\mathrm{C}_{4}$ crops have a higher light saturation level for photosynthesis than $\mathrm{C}_{3}$ crops (Anten and Hirose, 1999; Tilman et al., 1997; Trenbath, 1986). An intercrop of short $\mathrm{C}_{3}$ and tall $\mathrm{C}_{4}$ species might increase system light conversion efficiency resulting from complementary use of light, since the taller $\mathrm{C}_{4}$ species can express its higher photosynthetic capacity associated with its $\mathrm{C}_{4}$ pathway at high light (upper layer of the canopy), while $\mathrm{C}_{3}$ species may perform relatively better than $\mathrm{C}_{4}$ at low light intensity (e.g., lower canopy layer) (Anten and Hirose, 2003; Connor et al., 2011; Matthews et al., 1991; Willey, 1990). Such functional complementarity could further strengthen productivity increase arising from greater light acquisition due to differences in growth period.

\subsubsection{Options exist for combining acquisition and conversion efficiency gains}

$\mathrm{C}_{4} / \mathrm{C}_{3}$ relay intercrops in temperate zones make use of the differences in conversion efficiency between the two crop types and combine this with the enhanced light acquisition advantages of relay intercrops discussed above. While the earlier sown $\mathrm{C}_{3}$ crop makes use of extra light acquisition to overyield (Zhu et al., 2016), maturing while the $\mathrm{C}_{4}$ crop is still in early growth, the $\mathrm{C}_{4}$ crop makes use of the higher radiation and temperature in the temperate summer to recover from the earlier shading and produce comparable or more than proportional to its density. When this combination of $\mathrm{C}_{3} / \mathrm{C}_{4}$ includes a $\mathrm{C}_{3}$ legume, an additional advantage may come from the higher total nitrogen acquisition from air and soil in the intercrop as will be discussed below. Further research into the exact agro-climatic zones where this combination of an early sown $\mathrm{C}_{3}$ with a later sown $\mathrm{C}_{4}$ crop 
would overyield by making more effective use of total resource acquisition remains necessary. Field experiments can be combined with modeling studies to explore the scope for increasing both radiation and nitrogen acquisition in $\mathrm{C}_{3}$ legume/ $\mathrm{C}_{4}$ cereal intercrops or mainly radiation use in $\mathrm{C}_{3} / \mathrm{C}_{4}$ cereal intercrops.

\subsection{Water}

Analyzing water consumption of intercrops compared to sole crops can lead to a range of very different findings, and the potential of intercropping to conserve water is contested. Morris and Garrity (1993a) investigated 10 intercrops, reporting that water consumption by intercrops was only between $-6 \%$ and $+7 \%$ different from that by their combined sole crops, while water use efficiency of the intercrops was generally 4-99\% greater than that of sole crops, especially when water supply was not limited. Mao et al. (2012) described how a wheat/maize intercropping system was replaced by a $\mathrm{pea} /$ maize intercropping to lower the total water use of the system. In other words water use efficiencies may vary also between intercropping systems.

In the analysis of water the separation between water acquisition by the crop(s) and water lost from the systems conversion has not always been very strict. Morris and Garrity (1993a) for instance included transpiration and evaporation into water acquisition. Strictly speaking only the water transpired by the crop can be considered acquired and is used productively in crop growth. All water lost from the system in other ways, e.g., evaporation, drainage, or runoff, has not been acquired by the crop and does not contribute to growth. It is therefore desirable to separate crop transpiration from all other losses of soil water. However, practically speaking, metrics for water use of a system (e.g., WER as defined above) consider the total water use including all losses. Modeling, though, provides the tool to separate transpiration from other components of the water balance (Miao et al., 2016; Rosa et al., 2012; Tan et al., 2020). In most literature, no distinction is made between acquisition and conversion aspects of efficiency, here we review this to assess differences in overall use efficiency of water between sole crops and intercrops and explore plausible explanations for such differences.

\subsubsection{Evaporation losses depend strongly on management}

In principle, there is a negative relation between soil evaporation and crop transpiration. The aim in crop production is to maximize the transpiration component at the expense of the evaporation component of the total evapotranspiration and thereby improve the water acquisition efficiency. 


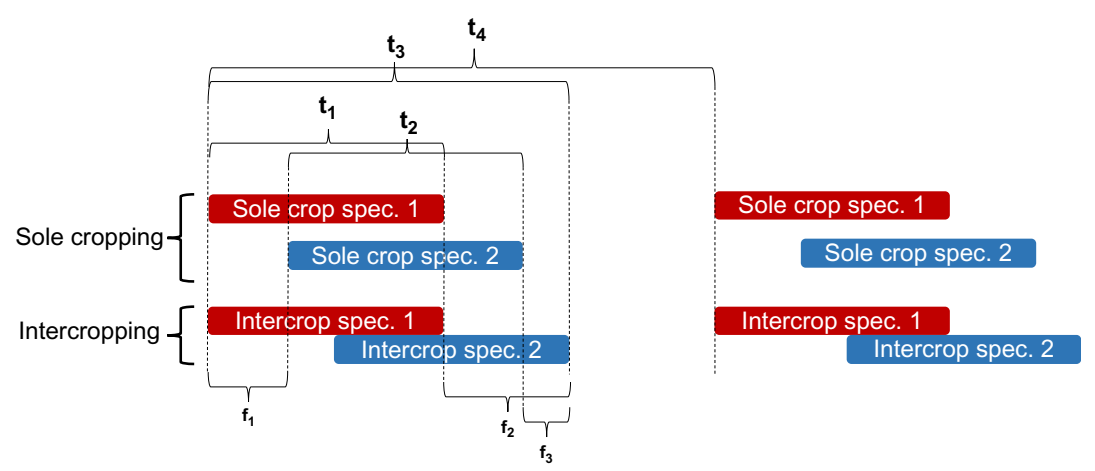

Fig. 4 Different temporal system boundaries delimitations relevant when comparing water use of sole and relay intercropping systems. Period $t_{4}$ indicates a full calendar year, $t_{1}$ and $t_{2}$ indicate the crop duration of the respective sole crops 1 and 2, while $t_{3}$ denotes the duration of the relay intercrop system. A valid comparison would require the use of $t_{4}$ or $t_{3}$ for both the sole and relay intercropping systems. Comparing water use during $t_{1}$ and $t_{2}$ for the sole crops with water use during $t_{3}$ for the intercrop overlooks evaporative loss of water in the fallow periods denoted with $f_{1}-f_{3}$ in the sole crop systems.

Relay intercrops are often found to have a significant larger total water consumption than their respective component sole crops (Coll et al., 2012; Miao et al., 2016; Yang et al., 2011), which can be explained by the extension of the total crop duration in relay intercropping ( $\mathrm{Li}$ et al., 2011) (Fig. 4). Water acquisition efficiency is often lower in strip intercropping than in sole crops (Gao et al., 2009; Szumigalski and Van Acker, 2008; Zhang et al., 2008), as a result of a larger water loss through evaporation from the bare strips under full field irrigation or in rainfed conditions. The extent to which additional water is lost through evaporation of bare strips largely depends on the frequency the soil surface is wetted by rain or irrigation, and the self-mulching capacity of the soil. In a system where only a few large irrigations were given, the water use efficiency increased with intercropping compared to sole cropping despite some evaporation from bare strips (Tan et al., 2020).

A proper comparison of total system water use will require a correct delimitation of the temporal system boundaries taking also water loss from fallow periods of sole crop systems into account (Fig. 4). Providing irrigation only to the cropped land area in relay cropping system would reduce inefficiencies through evaporation reduction, but may require more complicated irrigation methods. If rain falls during periods of sole-growth evaporation losses will occur from bare areas, but the same is true when sole 
crops are not preceded or followed by any other crop while rainfall occurs outside the cropping period of these sole crops. A correct analysis of the full system under rainfed conditions thus should take the full precipitation over the period the sole or intercrop is occupying the land, including possible fallow periods (periods $t_{3}$ or $t_{4}$ in Fig. 4).

The water acquisition inefficiencies in intercropping can be partly reduced by increasing planting density (Mao et al., 2012). Configuration influences water acquisition efficiency of intercropping because evaporation is highly affected by the canopy structure. The soil temperature will decrease due to a dense canopy and shaded soil surface, thus leading to a lower evaporation (Cooper et al., 1987). A dense canopy is often accompanied also by a lower soil moisture due to an increased transpiration by the canopy (von Arx et al., 2013), leading again to a reduced chance for evaporation, and in turn a higher water acquisition efficiency.

\subsubsection{Rooting patterns change the evaporation vs transpiration balance}

A cause of increased water acquisition efficiency in intercropping systems, especially when crops are sown simultaneously, is that water acquisition is increased due to increased root density in the upper layers, thus decreasing water lost by evaporation (Ghanbari et al., 2010; Walker and Ogindo, 2003). The extent to which species combinations lead to enhanced root growth is poorly documented. In the few papers that report on observed root length density or root biomass, though, intercrops always seem to have more roots in the top layer than sole crops (Cong et al., 2015b; Wang et al., 2014, 2015b).

Also complementarity of soil water acquisition may happen in intercropping, when there are differences in root distribution. The combination of deep-rooted and shallow-rooted species can allow acquisition of water resources in the deeper soil layers otherwise unattainable (Li et al., 2013). This spatial complementarity in water use has been found enhanced in cases leading to use of more water from deeper layers when water supply was limited (Yang et al., 2011). Roots of sorghum went deeper when intercropped with sunflower with a shallow root system, compared to the sorghum sole crop (Miyazawa et al., 2010) and in a maize/pea intercropping system, spatial differences in water acquisition between sole crops and intercrops indicated complementary rooting patterns (Mao et al., 2012). Using the ${ }^{32} \mathrm{P}$ tracer technique Hauggaard-Nielsen et al. (2001a) observed deeper rooting of spring barley than pea in an intercrop and also temporal differences in soil 
colonization rate, while water extraction with depth was more uniform in the intercrop than in either sole crop. Ongoing work in one of our groups, though, indicates that species interactions can also be more complex. In a combination of bristle oats (Avena strigosa L.) and fodder radish (Raphanus sativus L.), both species allocated more roots to the dry top soil under dry conditions apparently increasing competition rather than seeking complementary resource use as they did under moist conditions.

Intercrops may also benefit from temporal complementarity in terms of the presence of roots. In relay intercropping the first grown species starts with a larger area to extend its roots and after the harvest of the first crop the remaining crop may extend into the liberated area. This was observed indeed in a wheat/maize intercrop where the first sown wheat in the intercrop used a larger soil volume per plant, compared to sole wheat, while after the wheat harvest, maize occupied the full soil volume below the former wheat strips (Li et al., 2006, 2011).

It seems that a more systematic research of species combinations, conditions and mechanisms underlying complementary root allocation in space and time is warranted. With the recent development of three dimensional root system models (Postma et al., 2017), combinations of virtual experiments and field experiments will be possible to get maximum progress at reasonable costs as extensive research through only root system excavation, so-called shovelomics (Trachel et al., 2011), is rather expensive.

\subsubsection{No evidence for changes in water conversion efficiency}

$\mathrm{C}_{4}$ species have a higher photosynthesis rate per unit transpiration than $\mathrm{C}_{3}$ species (e.g., Mao et al., 2012), and thus an inherent higher water conversion efficiency. Overall water conversion efficiency of $\mathrm{C}_{3} / \mathrm{C}_{4}$ intercropping is reported to be intermediate between that of the $\mathrm{C}_{4}$ crop and the $\mathrm{C}_{3}$ crop (Coll et al., 2012; Gao et al., 2009). The water use efficiency (combining acquisition and conversion efficiency) of intercropping where maize, a $\mathrm{C}_{4}$ species, was intercropped with $\mathrm{C}_{3}$ species has been reported positively correlated with the proportion of maize (Mao et al., 2012), most likely because of the inherently higher water conversion efficiency of maize. To our knowledge there are no reports of changes in water conversion efficiency under intercropping compared to sole cropping. Thus, changes in water use efficiency by intercropping are to be understood as a consequence of a change in acquisition efficiency, not conversion efficiency. 


\subsection{Nutrients}

Intercropping has been shown to affect both nutrient acquisition, and conversion efficiencies of $\mathrm{N}, \mathrm{P}, \mathrm{K}, \mathrm{S}$ as well as important micronutrients such as $\mathrm{Fe}, \mathrm{Zn}, \mathrm{Mn}$, and $\mathrm{Cu}$. Nitrogen is a special case as it is the only plant nutrient with a non-mineral origin, for which air is the major store and which leguminous plants can acquire through symbiosis with bacteria, while it can also be applied as organic or synthetic fertilizer. Nitrogen will therefore be treated separately. For the other nutrients, some mechanisms are element specific but many are not, and they will be treated accordingly below.

\subsubsection{Nitrogen}

Legumes are commonly used in intercropping (Yu et al., 2015, 2016b). A key benefit of legumes is $\mathrm{N}_{2}$ fixation from air, enabling a reduction in fertilizer input in the crop system. When legumes and cereals are combined, the cereal usually takes a higher proportion of the soil $\mathrm{N}$ "forcing" the legume to rely to a greater extent on $\mathrm{N}_{2}$ fixation from air than when it is grown as a sole crop (Jensen, 1996). Thus intercropping can enhance $\mathrm{N}_{2}$ fixation by legumes making cropping systems less dependent on fertilizers, and can lead to an improved total nitrogen capture through niche complementarity between legumes and non-legumes (Li et al., 2013; Vandermeer, 1989). However, the total amount of $\mathrm{N}_{2}$ fixed by the legume can also be lower in intercrops compared to sole legume crops due to reduced biomass of the legume (Bedoussac et al., 2015). There is a need for judicial balancing of for instance relative sowing times of the cereal and the legume in an intercrop to optimize system performance (Yu et al., 2016b). Conversion efficiency does not seem essentially changed within a year, though cereals tend to be able to acquire more $\mathrm{N}$ toward the end of the season in intercrops than in sole crops when growing at lower $\mathrm{N}$, leading to enhanced grain quality (see Section 5.1) and enabling a recovery growth if a cereal is grown with a legume in a relay (Li et al., 2001).

It has been argued regularly that the advantage of non-legume/legume intercropping is of specific interest in low external input systems (Bedoussac et al., 2015; Bedoussac and Justes, 2010; Haugaard-Nielsen et al., 2008). The meta-analysis by $\mathrm{Yu}$ et al. (2015) question this assertion as in many systems intercrops were shown to be advantageous in terms of land use efficiency. Symbiotic nitrogen fixation by legumes is reduced/inhibited by $\mathrm{N}$ fertilization in high external input farming systems (Salvagiotti et al., 2008). Intercropping, however, through the greater competitive 
ability of the cereals for soil inorganic $\mathrm{N}$, alleviates the inhibitory effect of $\mathrm{N}$ fertilization on nodulation and $\mathrm{N}_{2}$ fixation of legumes ( $\mathrm{Hu}$ et al., 2017; Li et al., 2009). Mechanisms underlying this phenomenon may differ between crop combinations. Maize root exudates have been shown to promote flavonoid synthesis in faba bean, increasing nodulation, and stimulating nitrogen fixation (Li et al., 2016). If such direct stimulation always takes place or whether in other combinations the stimulation is more indirect through the reduction of mineral $\mathrm{N}$ in the rooting zone remains to be elucidated.

A re-analysis of the data from Li et al. (2009) (Fig. 3) using three quadrant analysis (van Keulen, 1982) shows that while maize acquired more nitrogen and produced more yield and biomass when fertilizer $\mathrm{N}$ was provided both in the intercrop and in the sole crop, the faba bean acquired comparable amounts over a wide range of fertilizer $\mathrm{N}$ applications most likely indicating that additional acquisition from soil $\mathrm{N}$ at higher fertilization rates was accompanied by an equal reduction in symbiotic $\mathrm{N}$ fixation. What the data further show is that compared to the respective sole crops both maize and faba bean acquired more $\mathrm{N}$. While for maize this follows the logics above, for faba bean this may indicate a stimulated symbiotic $\mathrm{N}$ fixation (Li et al., 2016). The single lines for each species across sole and intercropping for the relation between yield and $\mathrm{N}$ acquired (quadrant II, Fig. 3) also indicate the $\mathrm{N}$ conversion efficiency was identical in intercrop and sole crop and enhanced production per plant is explained fully by additional $\mathrm{N}$ acquisition per plant for both crops in this experiment.

A meta-analysis has shown that the effect of adding nitrogen to legume/ cereal intercrops on system productivity varies with temporal niche differentiation (Yu et al., 2016b). The positive effect of intercropping on system productivity in systems with high $\mathrm{N}$ input is enhanced with the difference in the growth period of the cereal and legume in the intercrop. The same effect is found whether the cereal or the legume is sown earlier. For both species groups earlier sowing implies a larger gain from the combination providing options for management depending on desired productivity of the companion species (Yu et al., 2016b).

Associated non-legumes can acquire $\mathrm{N}$ that is present in the legume rhizosphere (Chalk et al., 2014; Li et al., 2013; Thilakarathna et al., 2016) and the converse is also true (Johansen and Jensen, 1996). However, the amount of $\mathrm{N}$ that is "transferred" in this way from the legume to the non-legume crop species or the converse is rather small in annual intercrops and is typically below 15\% of the legume N (Chalk et al., 2014; Iannetta et al., 2013; 
Li et al., 2009; Thilakarathna et al., 2016), while substantial lower values have also been observed (Fan et al., 2006). The $\mathrm{N}$ that is transferred from the legumes to the non-legume and vice versa can come from root exudates and also from the decomposition of roots. Such transfer within a season as a result of decomposition of roots (including root nodules) could be especially relevant in relay intercropping systems in which the legume is sown before the non-legume (in many systems with maize). Such "transfer" of $\mathrm{N}$ between species with different seasonal growth patterns in an intercrop can also occur in intercrops of two non-legumes. For instance, Cong et al. (2015b) found that intercropping of two cereals (i.e., wheat and maize) conserved nitrogen in the soil system as compared to rotations of these two crops. A possible explanation would be acquisition of $\mathrm{N}$ released from decaying wheat roots by maize during the late summer, when wheat has cleared the field, but maize is actively growing. The later crop thus functions in the same way as a nitrogen catch crop (cover crop) would do.

\subsubsection{Phosphorous and micronutrients}

Intercropping affects bioavailability of nutrients such as $\mathrm{P}, \mathrm{Fe}, \mathrm{Zn}$, and $\mathrm{Mn}$, increasing their acquisition by the intercropped species (Li et al., 2014). Different crop species differ in their capacity to mobilize or access soluble inorganic forms of these elements and intercropping of different species can mobilize and increase acquisition for both species involved in the intercropping system. Most work on bioavailability of nutrients has focused on $\mathrm{P}$ as this is a major element limiting crop productivity due to low bioavailability in soil. The increase in $\mathrm{P}$ acquisition in intercrops can be because of higher $\mathrm{P}$ acquisition from poorly available organic sources or inorganic forms such as oxide and hydroxide complexes (Ae et al., 1990; Horst and Waschkies, 1987; Li et al., 2003, 2004, 2007).

Several legume species excrete organic acids or $\mathrm{H}^{+}$in their rhizosphere, enhancing the availability of $\mathrm{P}$ in the soil solution. Species with the ability to excrete organic acids include lupine, pigeon pea, chickpea, peanut, and faba bean, whereas most $\mathrm{N}_{2}$ fixing legumes will acidify the rhizosphere, due to an imbalance in the acquisition of cations and anions. Intercropping these $P$ solubilizing species with species that do not have this capacity enhances P acquisition of the latter (Ae et al., 1990; El Dessougi et al., 2003; Horst and Waschkies, 1987; Li et al., 2003, 2004). The mobilizing plant species release protons in surplus (Hinsinger et al., 2003) and/or carboxylates (Pearse et al., 2006; Vance et al., 2003) that solubilize the inorganic phosphate forms (Hassan et al., 2012; Hinsinger et al., 2011; Li et al., 2014) 
that can be recovered by the intercropped species on soils with low soil P availability (Hinsinger, 2001; Li et al., 2007). This acidification is most likely of special importance on calcareous soils. A meta-analysis carried out between two of our labs highlights the fact that the magnitude of additional $\mathrm{P}$ acquisition by the system is related to the extent to which the legume species is able to exude acids (Tang et al., in preparation).

On these same alkaline soils iron is present in the Fe(III) form which is not bio-available for higher plants (i.e., cannot be taken up). Similarly, on this type of soils the availability of $\mathrm{Zn}$ and $\mathrm{Mn}$ is reduced, compromising yields. The availability of $\mathrm{Fe}, \mathrm{Zn}$, and $\mathrm{Mn}$ can be affected by intercropping when Fe-mobilizing graminaceous monocotyledonous species (so-called strategy II plants; Marschner, 2011) are grown with legumes that do not have this ability to mobilize Fe, $\mathrm{Zn}$ and $\mathrm{Mn}$ (so-called strategy I plants) (Inal et al., 2007; Kamal et al., 2000; Zuo et al., 2000). The phytosiderophores that are released by cereal roots can mobilize Fe(III) so it can be taken up by both the cereal and the companion species, e.g., peanut. There is only limited information on the generality of such facilitative effects between grasses and legumes and whether advantages can be found beyond high $\mathrm{pH}$ soils, yet Xue et al. (2016) suggest this may be generally true for combinations of strategy II species (typically cereals) with strategy I species (typically dicotyledons).

In an earlier analysis of data from soils with a good P availability (Morris and Garrity, 1993b), an enhanced acquisition of $\mathrm{P}$ under intercropping was reported, beyond the increase in productivity. This led in the analyzed data to a decreased conversion efficiency. These authors related the enhanced acquisition to a larger root length density under intercropping and the decreased conversion efficiency to the fact other resources were more limiting than P. There is thus a need to more systematically analyze the effect on $\mathrm{P}$ recovery and conversion efficiencies beyond alkaline soils for balanced insight in $\mathrm{P}$ in intercropping systems.

\subsubsection{Potassium}

The higher yield that is found in intercrops compared with their respective sole crops also requires increased $\mathrm{K}$ acquisition. The $\mathrm{K}$ acquisition of three intercropping systems was enhanced by $22.5 \%$ comparable with the values expected based on the higher biomass production compared to sole crops (Wang et al., 2015b). This greater $\mathrm{K}$ acquisition in line with biomass overyielding has been observed more often (Choudhary et al., 2016; Singh and Ahlawat, 2012). Analyzing dynamics over the season Zhang et al. (2017) observe that cumulative $\mathrm{K}$ acquisition (per unit area basis) of intercropped 
crops was significantly lower than that of sole crops during early growth stages, and gradually showed higher $\mathrm{K}$ acquisition toward harvest. Application of $\mathrm{K}$ increased acquisition both in sole crops and intercrops, but more so in intercrops (Mondal et al., 2004). As for P, Morris and Garrity (1993b) reported an increase in $\mathrm{K}$ acquisition under intercropping larger than the increase in production leading to a lower conversion efficiency which they explained for both nutrients by an enhanced root length density and because other resources limited productivity in the analyzed intercropping systems.

\subsection{Interactions between resources}

While in general higher nutrient acquisition is reported in intercropping compared to the sole crops, there are reports where the nutrient acquisition $\left(\mathrm{kgha}^{-1}\right)$ of, e.g., $\mathrm{N}, \mathrm{P}$, and $\mathrm{K}$ of both species was reduced compared to sole cropping due to the competition between species in an additive intercrop of maize and mungbean (Chowdhury and Rosario, 1994). This lower acquisition may be interpreted as a consequence rather than a cause of lower biomass, as mass concentrations were comparable between sole and intercropped species. When light acquisition is changed, this changes available carbon also for root growth and thus acquisition capacity for nutrients and water, while additional growth will require additional water and nutrients to be sustained. Resource use efficiency of water or nutrients is mainly studied by providing the same water and nutrient input to the intercrop and to the sole crops. If then a yield gain is observed this leads to more production per unit input. Whether further yield gains could be obtained by providing resources in larger amounts, as indicated above for $\mathrm{K}$ (Mondal et al., 2004), or at a different timing in intercrops compared to their sole crops does not seem to have been studied very often. This because many intercropping studies are conducted with fixed inputs across treatments to allow a "fair" comparison of treatments. However, the sole crops and intercrops are likely to require tailored amounts and timing of water and nutrient resources. Studies on water (e.g., Yin et al., 2016) recognize the different water requirements of sole crops and intercrops, but fertilizer amounts are tailored less often (but see Yu et al. (2015) for an overview of variation in nitrogen fertilizer amounts in sole crops and intercrops in the literature). Gou et al. (2017a,b, 2018) found that maize in a wheat/maize relay intercrop had a lower light conversion efficiency due to nitrogen stress toward the end of the growing season. Further research is needed on tailored nutrition of intercrops. 
Proximity of companion species plays an important role in taking advantage of mixing (see van Oort et al., 2020 for light). Belowground, acquisition of water and nutrients from the soil solution is considered symmetric, i.e., both species that have root presence in the same part of the soil system have equal access to the resources, and acquisition and competition then depend mostly on the ability to acquire a resource when its concentration is lowered due to this acquisition. Aboveground, competition for light is strongly asymmetric. Here a winner takes (almost) all principle applies. Shading in most intercrops is done mostly by the nearest neighbor, but if there are substantial height differences between species, further away companion plants may cast enough of a shadow to affect growth. This applies for instance for maize and soybean. Plant growth is simultaneously co-limited by multiple resources, and in mixed systems, interactions between the competitive acquisition of light, water, and nutrients is to be expected. If any single resource is accessed better by a species, for whatever reason, in intercropping, then enhanced acquisition of the other resources is to be expected. Causal attribution is thereby very difficult and will often require modeling (Evers et al., 2019).

\section{Long-term effects on soil quality}

\subsection{Carbon}

Higher plant species diversity increases soil carbon (C) stocks in grassland ecosystems, which has been attributed to enhanced belowground input of organic matter in more diverse plant communities (Fornara and Tilman, 2008). In a long-term field experiment for intercropping with a replacement design over 7 years Cong et al. (2015b) found that soil organic C content in the top $20 \mathrm{~cm}$ was $4 \% \pm 1 \%$ greater in intercrops than in sole crops. Total root biomass in intercrops was on average $23 \%$ greater than the average root biomass in sole crops, reflecting below-ground overyielding, and providing a plausible mechanism for increased C storage in soil (Cong et al., 2015b). In contrast, using different chemical analysis methods, different treatments from the same experiment, and different metrics, Wang et al. (2015b) found that soil organic matter in all intercropping systems did not differ from the sole cropping. While Cong et al. (2015b) focused on intercrop systems that had an internal rotation of species within the species strips, the study of Wang et al. (2015b) considered all treatments, including intercropping in a monoculture setting over years. 
In another long-term field experiment established on an alkaline (pH 8.8) Orthic Anthrosol located in Gansu province, China, the treatments comprised maize/faba bean, maize/soybean, maize/chickpea and maize/ turnip intercropping, and their corresponding sole crops. Soil organic matter $(\mathrm{OM})$ did not differ significantly between intercrops and sole crops but did increase in maize/chickpea in 2012 (the 4th year) and maize/turnip in 2011 (the 3rd year) and 2012 (Wang et al., 2014). Given the rate of organic matter accumulation in soils, experiments with a duration of at least 10 years may be needed to establish trends.

Soil organic matter (SOM) from intercrop plots decomposed faster than SOM from sole crop plots (Cong et al., 2015a), one plausible reason being the $8 \%$ higher organic $\mathrm{N}$ content in the soil at only marginally greater $\mathrm{C}$ content (Cong et al., 2015b). A decreased C/N ratio is likely to facilitate decomposition (Booth et al., 2005). In addition, the greater root litter $\mathrm{C}$ input in intercrops compared to sole crops would lead to a faster rejuvenation of the SOM pool with more labile SOM (since the start of the experiment, 7 years prior to the measurement) resulting in a higher relative decomposition rate (Cong et al., 2015a). The higher production of crop residues in intercrops may contribute positively to soil carbon levels in the long run, if these residues are left in the field.

\subsection{Nitrogen}

Higher plant diversity enhances soil $\mathrm{N}$ availability and retention in grassland systems (Dybzinski et al., 2008). In three-component intercrops, wheat/ maize/soybean intercropping increased soil total $\mathrm{N}$ by $9.4-38.6 \%$ but wheat/maize/sweet potato intercropping reduced soil total $\mathrm{N}$ by 1.8-14.0\% compared to the respective sole crops (Wang et al., 2012; Yong et al., 2012). In a long-term field experiment, Cong et al. (2015b) reported that soil organic $\mathrm{N}$ content in the top $20 \mathrm{~cm}$ was $11 \pm 1 \%$ greater in intercrops than in sole crops, indicating a difference in $\mathrm{N}$ sequestration rate between intercrop and sole crop systems of $45 \pm 10 \mathrm{kgNha}^{-1} \mathrm{yr}^{-1}$. Compared to the corresponding monocultures, the soil $\delta^{15} \mathrm{~N}$ signature suggested that increased biological $\mathrm{N}$ fixation and/or reduced gaseous $\mathrm{N}$ losses contributed to the increases in soil $\mathrm{N}$ in intercrop rotations with faba bean. Quantification of relative contributions remains uncertain. Increases in soil total $\mathrm{N}$ in a wheat/maize intercrop pointed to contributions from a broader suite of mechanisms for $\mathrm{N}$ retention, e.g., complementary $\mathrm{N}$ acquisition strategies of the intercropped plant species and reduced 
losses from leaching or volatilization (Cong et al., 2015b). However, similarly as for soil carbon, Wang et al. (2015b) reached contrasting conclusions from the same experiment. Results from Cong et al. (2015b) are in agreement with findings in natural systems where plant species diversity serves to keep nitrogen in the system, even in intercrops not containing legumes. In another long-term experiment comparing four intercropping systems, soil total $\mathrm{N}$ did not differ between intercropping and sole cropping (Wang et al., 2014).

The differences in conclusions and study methods for both nitrogen and carbon as reported above point to a need for intensified attention to proper methods in intercropping research. This concerns many aspects, including the design of short and long-term experiments, the formulation of null hypotheses, the design of sampling methods for soil properties to take into account potential spatial variability, the calculation of metrics to compare sole crops, rotation systems and intercrops (either grown as rotation or continuous cultivation year after year on exactly the same location), and the choice of chemical analysis methods.

Accumulation of nitrate in the soil increases the risk of nitrate leaching during a fallow period with rainfall excess and hence possible ground-water nitrate pollution (Almasri and Kaluarachchi, 2004). In wheat/maize and maize/faba bean strip intercropping systems, Li et al. (2005) found that the amounts of $\mathrm{NO}_{3}^{-}$present in the soil after wheat and after maize harvest was consistently lower in the intercrop than in corresponding sole crops. The results show that intercropping decreased the residual nitrate in the soil profile ( $\mathrm{Li}$ et al., 2005), which is in line with the enhanced productivity in the intercrops. In some sole crops (barley, oat, pea or clover) or cereallegume intercrops in the east of Scotland, nitrate leaching was reduced under intercrops when compared with the barley sole crop. The legume cultivar seemed to determine the extent of loss reduction (Pappa et al., 2011). A recent study showed that the emissions followed lower increases of $\mathrm{N}_{2} \mathrm{O}$ through an influence of intercropping on both nitrification and denitrification (Ricord, 2018).

\subsection{Phosphorus and potassium}

The increase in productivity generally seen under intercropping is most likely accompanied by an equivalent increase in nutrient acquisition, but there is limited data available. In a 3 year study soil Olsen-P was found to have decreased by $7.5-19.5 \%$ under intercropping compared with that in 
the sole crops over a range of $\mathrm{P}$ fertilization levels (Xia et al., 2013a). Though, in other studies no difference in available $\mathrm{P}$ were observed between bulk soil samples across a range of cropping systems (Dissanayaka et al., 2015; Tang et al., 2014). Soil exchangeable K decreased by 5.1-26.6\% in legumes/ maize intercropping in comparison with the corresponding sole crops under no K fertilization (Wang et al., 2014), meanwhile continuous intercropping (6 years) depleted available soil $\mathrm{K}$ by $61.6-62.5 \%$. Also in other studies a negative $\mathrm{K}$ balance was observed in both sole crop and intercropping (Blaise et al., 2005), while in cases this was shown to be alleviated by application of P (Wang et al., 2014) or N fertilization (Mondal et al., 2004).

All-in-all, few data exist on long-term effects of intercropping. If supplied with equivalent amounts of nutrients and productivity is enhanced intercrops can be expected to mine the soil better for elements that are not otherwise lost from the system. Also nutrient losses may be reduced by better acquisition, and increased carbon input can help to boost organic matter and thereby nutrient retention and associated crop performance. Whether and to what extent enhanced acquisition is compensated by reduced losses in the case of mobile elements like $\mathrm{K}$ (and $\mathrm{N}$ ) cannot be concluded from available literature. There is a need for further experimentation and critical evaluation of methods and metrics to assess long-term effects.

\section{Climate change, yield stability and resilience to stress}

Global warming and higher frequency of extreme weather events (IPCC Climate Change, 2007) increase climate risks for agriculture in many regions (Craufurd and Wheeler, 2009). Adaptation of cropping systems to climate change will play an important role in future food security and long-term sustainability of food systems (Rusinamhodzi et al., 2012). There are many options for adapting to climate change and variability. Intercropping can contribute through increased resource use efficiency (Section 2 above) and yield stability under conditions of variable rainfall and adverse temperatures.

\subsection{Yield stability}

Projected climate scenarios may significantly decrease yield and yield stability in sole crop-based cropping systems that are optimized for current conditions, but potentially less adapted for "new" conditions not previously experienced. Mixing species in an intercrop reduces the likelihood of complete failure due to abiotic or biotic stress because of trait divergence 
between the species (Lithourgidis et al., 2011; Rao and Willey, 1980). One species may be harvested earlier than the other(s), loosening competition on the remaining species and resulting in compensatory growth (Zhang and $\mathrm{Li}$, 2003). Compensation takes place when (a) well performing species effectively use(s) the resources remaining available due to the non-acquisition by (the) species that is (are) affected by stress. Species complementarity in resource use also contributes to greater yield stability. In summary, the different principles of species interactions in intercrops lead to stabilization of the intercrop yield over years or between sites as compared to sole crops (e.g., Jensen, 1996).

Rao and Willey (1980) made an analysis of 94 experiments confirming the hypothesis that intercrop yields are more stable than sole crop yields. Raseduzzaman and Jensen (2017) recently confirmed this finding based a meta-analysis of 33 studies published since 1980. The analysis considered intercrop species combinations (cereal/grain legume, non-cereal/grain legume), experimental patterns (experiment over years, experiment over locations), intercropping designs (additive vs replacement) and climatic zones (tropical, subtropical, and temperate). The coefficient of variation of yields from studies with minimum 3 years of field experimentation or sites was used as a simple indicator for assessing yield stability (Raseduzzaman and Jensen, 2017). The observed lower coefficient of variation for intercropping indicated higher yield stability.

The meta-analysis showed that cereal/grain legume intercrops significantly increased yield stability of the combined grain yield compared with the respective grain legume sole crops (coefficient of variation of $22 \%$ for the intercrop and $32 \%$ for the grain legume sole crops). Intercrops were also more stable than cereal sole crops (Raseduzzaman and Jensen, 2017). Compared with the respective cereal and legume sole crops (coefficient of variation of 25 and 30\%, respectively), intercrops in replacement designs had significantly higher yield stability (coefficient of variation of 19\%). In tropical regions, cereal sole crops had lower yield stability than intercrops and legume sole crops. However, intercropping in all climatic zones showed higher yield stability than both sole crops. A positive correlation was observed between productivity and this measure of yield stability (Raseduzzaman and Jensen, 2017). Döring et al. (2015) pointed to the risk associated with the use of stability indicators, which are related to the size of the mean yield, such as \%CV. The relation between variability and mean yield may lead to an apparently lower stability of lower yielding crops as compared to higher yielding crop. Therefore, it is relevant to also 
consider measures of absolute variability, e.g., standard deviation, or other metrics. One could also characterize the functional form of the relationship between variability and the mean, e.g., using Taylor's power law and power law residuals (Döring et al., 2015).

Intrinsic yield stability as a result of diversity and complementarity is especially important in cropping systems with lower inputs of pesticides or synthetic $\mathrm{N}$ fertilizer. The possible trade-offs between stability and yield level at increasing weather variability and extreme events should better be analyzed on the basis of underlying mechanisms than purely using statistical methods. From a food systems perspective it seems relevant to develop metrics that compare variability of combined nutritional output of systems rather than the yield variability of the combined grain yield of intercropping and sole cropping systems.

\subsection{Abiotic stresses: Coping with future climates}

Under the current climate, intercrop production is already significantly affected by weather variability, especially in semiarid regions. In waterlimited environments, seasonal rainfall variability and arrangement of intercropping time, space and species combinations are key factors determining production risks. Farmers in such environments have a long tradition in using intercropping as an element in their risk coping strategies (Vandermeer, 1989).

Crop modeling (Holzworth et al., 2014; van Ittersum and Rabbinge, 1997; Wallach et al., 2014) is a useful tool to study interactions between genetic, environmental, and management factors $(G \times E \times M)$ needed also to combine the complexity of climate change with that of agro-ecosystems (Yang et al., 2017). Crop models can translate climate variability into yield and environmental impacts, while accounting for different management strategies and tactics (Meinke and Stone, 2005). However, the platforms used for this research do not at present include sufficient capabilities to analyze intercrops. The APSIM model framework (Keating et al., 2003) has been used extensively for the evaluation of climatic risks and for providing quantitative advice at farm and policy levels (Nelson et al., 2007) in many parts of the world such as Australia (Meinke and Stone, 2005), East Africa (Twomlow et al., 2008), India (Meinke et al., 2006) and China (Chen et al., 2010). Including intercrops as an option into such a tool will enhance our capacity to analyze further the potential role of intercropping in maintaining food systems in future climates. However, as yet, crop models 
for intercropping have mostly been developed for fully mixed crops, using the assumption of horizontally homogeneous canopies, and only considering differences in the vertical profiles of leaf area density between the component crops. For instance, a leek-celery intercropping model was applied to analyze the land productivity in which the crop canopy was treated as homogeneous because of the row by row design of this intercrop (Baumann et al., 2004; Kropff and Goudriaan, 1994). However, for many strip intercropping designs or more complex row designs both temporal and spatial heterogeneity should be explicitly included in the model because predictions from models assuming full intercrops and models using strip intercropping assumptions differ (Gou et al., 2017b).

To better integrate intercropping into the climate change research we propose the following priority research aims (1) develop and validate a strip intercropping module for various intercropping combination and climate conditions in a well-tested model platform such as APSIM; (2) define the contribution of intercropping to productivity and environmental sustainability under climate change at both field and regional levels; (3) evaluate the climate risks and opportunities to adapt agriculture including intercropping systems by, e.g., shift sowing windows (Howden et al., 2003).

\section{Biotic stress}

After the treatment of abiotic resources and conditions we will here discuss the effects of intercropping on biotic stresses separating diseases, pests, and weeds. While biotic stresses are not directly linked to resource use, they do influence or may be influenced by both resource acquisition and conversion through their interaction with the plant. The effect of intercropping can be a reduction of the biotic stress through for instance a dilution of host density when species are mixed or in the case of weeds through a more effective temporal and spatial competitive ability of the intercrop than the component sole crops, allowing less weeds to establish. The effect can also be a reduction in the severity of the effects of the biotic stress as a result of compensation between species if one of them is affected by diseases and pests. In this section, the focus will be on effects of single organisms on crop performance and not on the interaction between biotic and abiotic stresses or between biotic stresses and resource use. 


\subsection{Disease control by intercropping}

Intercropping reduced disease in 73\% of more than 200 studies (Boudreau, 2013), including fungi, oomycetes, viruses, bacteria, nematodes and parasitic plants. Disease severity reduction can raise up to $80 \%$, depending on the disease and level of epidemics. The types of diseases with the highest proportion of studies reporting disease level increase under intercropping are nematodes and viruses.

Underlying mechanisms affecting epidemics include vector dispersal (through wind and/or rain), modification of microclimatic conditions within the canopy, plant and organ nutrition status and ontogeny and subsequent receptivity to the disease, and plant nutrition status (Zhang et al., 2019). Most reported effects are linked to reduction of host density (so-called dilution effect). While single mechanisms have been demonstrated being active in some disease reduction, the relative importance of different mechanisms depending on pathosystems and designs (species combinations, spacing, density) needs further analysis.

Mixing species dilutes the proportion of hosts in a mixed canopy for pathogens, while physical barriers are formed that interfere with pathogen spread. Root exudates in intercropping may allelopathically inhibit the growth of pathogens and reduce their survival and infection potential (Hao et al., 2010; Li et al., 2018; Qin et al., 2013; Yang et al., 2014). Microclimate (such as temperature, moisture and aeration conditions; Gomez-Rodriguez et al., 2003) and the soil micro-ecological environment (such as rhizosphere microflora, community structure and diversity as well as soil enzyme activities) are modified often supporting a disease control effect by intercropping. Physiological and biochemical characteristics of host crops are modified, and putatively modify receptivity of crops to pathogens (Schoeny et al., 2010).

Air-borne plant diseases occur generally in the main growing period during warm and moist conditions, and their prevalence is closely related to planting density of host crops, planting distance, the available inoculum of pathogenic fungi and their pathogenicity, field onset conditions such as temperature, humidity and wind speed (Zhu et al., 2005). Compared with monoculture glutinous rice (susceptible variety), intercropping of the same glutinous rice and non-glutinous rice (resistant varieties) reduced the incidence of glutinous rice blast by $90 \%$, and the incidence of non-glutinous rice blast by $30-40 \%$ (Zhu et al., 2005). 
Examples of intercropping effects on soil-borne disease include wheat/faba bean where the prevalence of fusarium wilt (Fusarium oxysporum f.sp. fabae) in faba bean (as measured by disease index) was reduced by 57 and $42 \%$, respectively, on two varieties of faba bean (YD324 and FD6) when grown with wheat compared to its sole crop. Pepper blight (Phytophthora capsici) did spread across maize rows to other pepper rows in an intercrop of pepper with maize (Yang et al., 2014). The authors postulated that the maize row interfered with the movement of zoospores of the pathogen in the root zone. Compared with sole pepper, the disease index of pepper blight in the maize/pepper intercrop decreased by 34,49 , and $46 \%$, respectively, in three consecutive years.

\subsection{Intercropping effects on diseases: An analysis based on vote counting}

As shown by the examples above intercrops may suppress plant diseases, but the literature also reports, lack of effect, or even stimulation of plant diseases. To allow a first insight into the general trend we searched the literature to find publications that report primary research data on disease severity and incidence in experiments with both intercrop treatments and sole crops. The data were summarized using a simple vote counting method.

In January 2018, we made a literature search in the data base Scopus, using a search phrase looking for a combination of intercrops (including synonyms) and plant diseases in the title, abstract and keywords of the paper. Furthermore, this search phrase excluded papers that aim at modeling, papers that are on mycorrhizal associations, and papers that are on intercropping effects on nematodes (included below under pests). The search yielded 575 papers. We used six selection criteria to select only those papers that contained primary information on plant disease incidence or severity, based on field observations. The selection criteria were (1) only intercrops of annual crops, (2) only field experiments (no pot or glasshouse experiments), (3) no (agro)forestry, (4) only plant diseases (virus-like, bacteria, fungi-like), (5) symptoms caused by infectious agents, not by nutrient deficiencies, (6) only primary information, so no reviews.

After this selection, 101 papers remained. From the 101 papers, we extracted information on whether intercropping decreased or increased disease severity or incidence, or whether it had no effect. One paper could yield multiple outcomes, for instance if it had multiple years of data, different crop species, or different diseases within a crop species. 


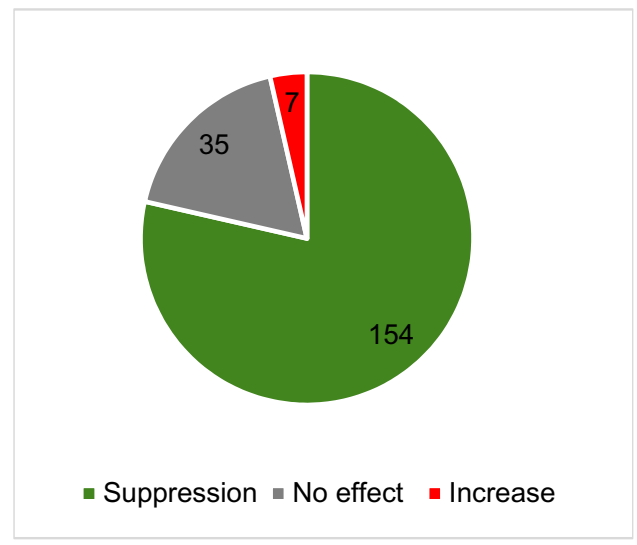

Fig. 5 Result of vote counting analysis on the effect of intercropping on disease incidence or severity in published literature on annual intercrops obtained with the search phrase on Scopus: TITLE-ABS-KEY (intercrop* OR "plant mixture*" OR "species mixture*") AND TITLE-ABS-KEY (disease* OR fung* OR virus* OR pathogen*) AND NOT TITLE-ABS-KEY (model* OR mycorrhiz* OR nematode*). A total of 196 cases (unique publication-crop-pathogen combinations) were obtained.

In each instance, we noted the outcome as decrease, increase or no effect. 196 "votes" were thus obtained from 101 papers. Out of 196 cases (unique publication-year-crop-pathogen combinations), 154 cases represented disease suppression (79\%), 35 represented no effect (18\%), while seven cases represented an increase (3.6\%) (Fig. 5). The overriding effect of intercropping is thus a reduction in plant diseases. Experiments in Africa, North America + Europe and Asia showed a similar prevalence of disease suppression: 79,73 , and $87 \%$ of cases, respectively.

Overall, the literature search indicates that intercropping overwhelmingly reduces plant diseases. Further literature analysis is needed to quantify the size of the disease suppressive effect of intercropping, and identify key factors affecting disease suppression, e.g., crop species, agro-climatic zone, legume vs non-legume or fertilizer level. Such an analysis will provide important information for the design of intercropping systems in cases sole crops currently show large losses or depend heavily on pesticides for disease control. It will also define a further research agenda into the understanding of the most important underlying processes, in turn needed for further improving designs.

\subsection{Intercropping effects on pests}

The same vote counting method was used to make a semi-quantitative inventory of the available literature on the effects of intercropping on pest 
incidence and severity. This literature search was carried out on February 20, 2018 on the database Scopus, associating "intercropping" with "pests" and extending the search with common pest phyla, yielding 326 papers.

We used four selection criteria to filter out those papers that contained primary information on pest incidence or severity, based on field observations. The selection criteria were: (1) studies based on annual intercrops only; (2) field studies, so no pot or glasshouse studies; (3) reporting primary data, so no reviews, theoretical or modeling studies; (4) exclusion of weeds (see Section 5.4). After this selection, 153 papers remained, from which we extracted information. A total of 546 "votes" were thus obtained as one paper could yield multiple outcomes, for instance if it had multiple years of data, different crop species or different pest organisms within crop species. In each instance, we noted the outcome as decrease, increase or no effect.

A total of 128 unique crop species from 22 plant families were used in the experiments. The most important groups of crops are shown in Fig. 6A. Legumes are most often used in studies on intercropping effects on pests followed by cereals. Maize (Zea mays) and cowpea (Vigna unguiculata) were by far the most frequently occurring crop species. A reduction in pests was found in $68 \%$ of the cases against an increase in $8 \%$ and no effect in $24 \%$ of the studied cases (Fig. 6B), in other words a generally positive effect in terms of crop protection.

A

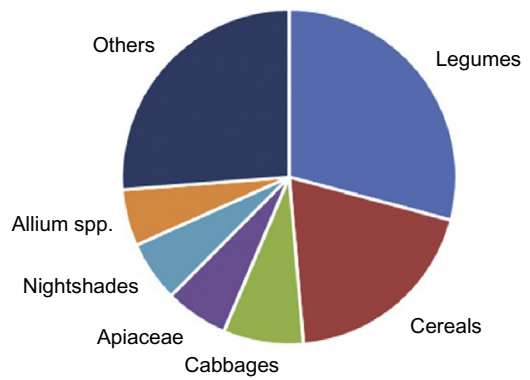

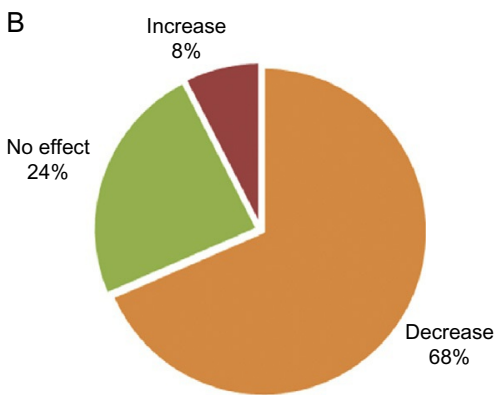

Fig. 6 Summary of the vote counting analysis on pests in intercropping for literature obtained on Scopus with the search string: (TITLE (intercrop*) OR TITLE ("plant mix*") OR TITLE ("species mix*") AND TITLE-ABS-KEY (pest*) OR TITLE-ABS-KEY (insect*) OR TITLE-ABS-KEY (arthropod*) OR TITLE-ABS-KEY (mite) OR TITLE-ABS-KEY (gastropod*) OR TITLE-ABS-KEY (nematod*) AND NOT TITLE-ABS-KEY (tree) AND NOT TITLEABS-KEY (review)). (A) Crop species used in studies on pest control by intercropping and $(B)$ the reported effect of intercropping on pests. 
A further analysis of the retrieved literature may allow an analysis of underlying processes and possible design criteria for combinations for systems where pests are a major biotic stress.

\subsection{Effects of intercropping on weeds: An analysis based on vote counting}

Intercropping has been seen as an effective way to reduce weed pressure. Beside the literature that reports weed suppression, however, some papers report intercrops that lack an effect or stimulate weed growth. Also for weeds we conducted a simple vote counting analysis of the literature to obtain a semi-quantitative synthesis. A search of peer-reviewed literature in the Web of Science database was conducted September 2018. The initial search included two expressions which targeted studies related to a combination of intercropping (including synonyms) and its effect on weed, for papers published between 1945 and 2018. This search yielded 801 publications, from which papers were selected based on four criteria (1) primary research papers, so no reviews; (2) intercropping of two annual plant species only; (3) the study includes data on the intercrop and the sole crop treatments; (4) only field experiments (neither pot or glasshouse experiments, nor modeling). A total of 120 articles remained from which 223 "votes" were obtained on which we extracted information related to the effect of intercropping on weeds (decrease, no effect or increase). One paper could yield multiple outcomes, when it reported different crop combinations, different experiment sites or several years of experiments. Among the 223 "votes," 191 cases represented weed suppression (86\%), 27 represented no effect (12\%), while five cases represented an increase (2\%) (Fig. 7A). Experiments in Africa, Asia, North America, South America and Europe showed slightly different percentages of weed suppression: 98, 92, 70, 100 , and $85 \%$, respectively.

The papers covered 83 different crop species, which were categorized into five groups: maize, cereals (other than maize), legumes, vegetables, and others. Calculated result showed that legumes, cereals and maize were the most studied groups or species, accounting for 50,23 and $12 \%$ of the data, respectively, while proportions for vegetables and others were only 11 and 4\% (Fig. 7B), respectively.

Some systems involved the intercropping of two cash crops, while other intercrops combined a cash crop with a cover crop, which is sown not to be harvested, but to provide other benefits, such as decreasing the risk of crop failure, controlling weeds and pests, and improving soil fertility 
A

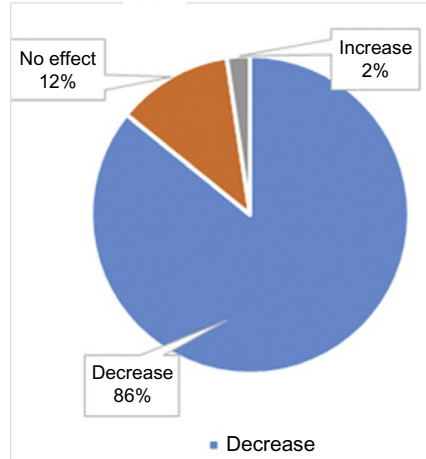

B

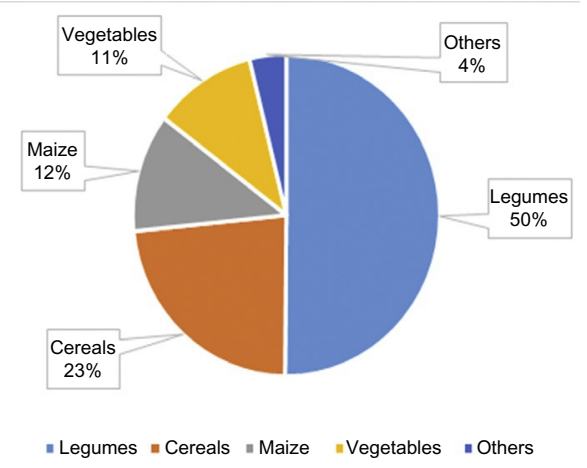

Fig. 7 Result of vote counting analysis on the effect of intercropping on weed biomass (208 votes), weed density (10 votes) or weed counts (5 votes) in published literature obtained on Web of Science with the search phrase: TOPIC (intercrop* or "mixed crop*" or "crop mix*" or "mixed cult*" or polycultur*) AND TOPIC(weed*) NOT TOPIC (vineyard OR pastures OR grassland OR orchard OR agroforestry) and (A) reported as decreased, increased or no effect, $(B)$ frequency of studies on different crop categories.

(Liebman and Dyck, 1993). The proportion of intercrops consisting of cash crops that reduced weeds (57\%) slightly exceeded the proportion of cash crop/cover crop systems that did so (42\%).

In general, the literature search indicates that intercropping reduces weed emergence. Further literature analysis is needed to quantify the size of the weed suppressive effect of intercropping and the ensuing effects on crop production and weed population dynamics, and identify key factors affecting weed suppression, e.g., crop combinations and configuration, sowing and harvest date, weeding operation or fertilizer level. Such an analysis will provide important information for the design of intercropping systems that could make agriculture less dependent on herbicides, fossil energy or hard labor for weed control.

Overall the three vote counting analyses of the literature seem to indicate that there are large gains to be made in reducing biotic stress by well-chosen intercrop combinations. The employed method of vote counting has been criticized for three major reasons (Koricheva et al., 2012), (i) it does not take into account differences in the number of replicates between studies and (ii) the magnitude of effects cannot be established (iii) the method does not use the power of true meta-analyses by combining the size of non-significant effects into a meta-analysis so it may erroneously lead to the conclusion there is no effect. In relation to the last two points, indeed 
we agree that for a full insight meta-regression analyses would be preferable, but the method provided a clear reason to expect large advantages. As we have combined agronomic studies that used between three and six replicates the first point is less relevant.

\section{Product quality}

Most focus in agronomic research, has been on productivity and resource use. Since the 1990s, though, there is a growing body of research focusing also on product quality. From a food systems perspective human nutritional needs have been translated in the need to provide not just quantity but also quality in terms of proteins, vitamins and other micronutrients (Graham et al., 2007). From a value chain perspective, consumer and industrial requirements in principle translate into price differences of products of different quality. Taking these aspects into consideration we here analyze available literature on possible effects of intercropping on product quality. Two aspects have been found reasonably well researched, grain protein of small cereals in cereal/legume intercropping and grain iron and zinc concentrations of intercrops grown under alkaline conditions.

\subsection{Cereal and legume grain protein concentration}

Effects on cereal grain protein concentrations as element of cereal quality seem to have been studied essentially for low $\mathrm{N}$ input systems where grain protein concentrations are an aspect determining price and thus economics of the crop. Gooding et al. (2007) reported a positive effect of intercropping wheat with legumes on the cereal grain protein concentration indicating this was due to a higher available soil $\mathrm{N}$ for the cereal on a per plant or a per grain basis in intercrop in comparison with sole crops (cf. Section 2.3). It was shown to be the result of: (i) the low competitiveness of legumes for nitrogen compared with cereals, combined with (ii) competition for light, water and other nutrients, between the two species, which led to reduced cereal biomass and yield. Indeed, this effect is only possible if the total quantity of available soil nitrogen for the cereal is not reduced by the legume $\mathrm{N}$ acquisition in the intercrop in the same proportion as the cereal yield is reduced. As intercropped legumes generally obtain a large part of their nitrogen from $\mathrm{N}$ fixation (cf. Section 2.3.1) a larger share of soil $\mathrm{N}$ remains available per cereal plant when grown in intercrop than when grown as sole crop. Indeed, in an analysis of 58 intercrop experiments under organic growing conditions, an average $27 \%$ of the nitrogen 
accumulated in the aboveground biomass of the intercropped legume came from the soil while $73 \%$ of the nitrogen was derived from air (Bedoussac et al., 2015).

Intercropping cereals with legumes improves cereal grain protein concentration compared with sole cropping especially under low soil nitrogen and with low $\mathrm{N}$ input (e.g., Bedoussac and Justes, 2010; Gooding et al., 2007; Jensen, 1996; Knudsen et al., 2004; Naudin et al., 2010). Naudin et al. (2010) showed that in unfertilized wheat/winter pea intercrops the wheat grain protein concentration was comparable to sole cropped wheat fertilized with $18.5 \mathrm{~g} \mathrm{Nm}^{-2}$. Legume grain protein concentration was similar in sole crops and intercrops (24.9\%) likely due to the ability of the legumes to fulfil their nitrogen requirements by $\mathrm{N}_{2}$ fixation.

The enhanced protein concentration of the intercropped cereal could also be partly explained by a better fit between the temporal dynamics in nitrogen requirements of the cereal and soil nitrogen availability. A change in the availability of nitrogen at a stage when acquisition by the cereal is still possible and acquisition does not affect productivity as much as it does grain protein density. This implies that a limited effect of intercropping on grain protein concentration can be expected when more $\mathrm{N}$ is available. Here intercropping shows its greatest potential in systems with low nitrogen availability, where the equilibrium between fixation and absorption of soil nitrogen by the two species allows an adjustment of the availability to the cereal needs (Corre-Hellou et al., 2006; Fujita et al., 1992; Hauggaard-Nielsen et al., 2001a,b, 2003; Naudin et al., 2010; Tofinga et al., 1993).

\subsection{Cereal and legume grain micronutrient concentration}

Grain micronutrient densities are influenced by intercropping. As indicated above (Section 2.3) micronutrient acquisition by legumes has been found to be enhanced on calcareous soils by mixing with cereals and in some cases increased allocation of micronutrients to grain was found. Zuo et al. (2003) and Zuo and Zhang (2007) found mutual facilitation of micronutrient acquisition in a maize/groundnut intercrop where groundnut was able to increase the acquisition and seed concentrations of $\mathrm{Fe}, \mathrm{Zn}$ and $\mathrm{Cu}$ and maize $\mathrm{Fe}, \mathrm{Mn}, \mathrm{Cu}$, and $\mathrm{Zn}$ concentrations in grains. In another study maize grain concentrations were reduced when intercropped with legumes and unaffected when intercropped with turnips (Xia et al., 2013b), as total plant uptake was not affected or slightly increased and biomass increased the 
effect seemed mainly a dilution effect. In a study on strip intercropping of maize with oats (Avena sativa L.) or lupin (Lupinus angustifolius L.) maize grain showed a higher Fe concentration in the border row with lupin but not with oats (Glowacka, 2013) again indicating a possible positive effect of the legume on the cereal.

As grain allocation of micronutrients like, e.g., $\mathrm{Zn}$ is linked to grain $\mathrm{N}$ allocation in cereals (Kutman et al., 2011), the higher grain $\mathrm{N}$ levels discussed in Section 6.1 might be accompanied by and explain a higher grain $\mathrm{Zn}$ allocation. This and other possible effects of intercropping on product quality seem relevant from a food systems perspective but are too poorly studied to report clear trends. The limited available literature may either indicate a knowledge gap or a rather small effect on product quality. Further research, e.g., through more systematic data acquisition on quality aspects during experiments, will be necessary to allow a more final insight into possible quality effects of intercropping and their relevance.

\section{Synthesis and outlook}

Intercropping leads to land use advantages across the world. This advantage is expressed by land equivalent ratios in the order of 1.2-1.3 (Martin-Guay et al., 2018; Yu et al., 2015). This means that, on average, the yield per plant in intercrops is increased when compared to the yield per plant in sole crops. Indeed, plants in intercrops often show overyielding, and this is associated with plastic responses that allow the plants to acquire more resources. For instance, wheat in intercrops with maize has substantially more tillers per plant than wheat in sole crops (Zhu et al., 2015, 2016). The yield advantage that is associated with LERs greater than one is due to competitive relaxation, an overall reduced intensity of competition over time and space in the mixed crop as compared to the sole crop. As a result of this competitive relaxation, resource acquisition per each species is greater in the intercrop than would have been expected on the basis of resource acquisition in the sole crop. This is true for all the main resources: light, water and nutrients. Furthermore, pests, diseases and weeds are been found generally suppressed when studied in intercrops, reducing the negative effects of these growth reducing factors. Competitive relaxation is synonymous to complementarity; the species complement each other in resource acquisition in time and space, such that competition for those resources is relaxed compared to sole crops. 
Intercrops can be designed to take maximum advantage of the potential for complementarity. This design should consider species choice, variety choice, input levels, sowing dates, and spatial configuration. The design should take into account the growing conditions. As a rule, the optimal crop combination will be one that can fully acquire the available resources and overcome negative aspects of the production situation, such as soils with low availability of essential nutrients, e.g., $\mathrm{P}$ and $\mathrm{Fe}$, or strong biotic stress derived from diseases or pests.

At the potential production level (Fig. 2), complementarity for light acquisition is the driver for high productivity in intercropping. When the production situation is potential, water and nutrients are sufficiently available by definition, and competition for these resources will be minimized. However, competition for light will always be there. If high yield is the aim, then total light interception over the season should be maximized (Monteith, 1977). The aim of high light acquisition can be realized by exploiting differences in phenology between species. Yu et al. (2015) showed how temporal complementarity between species in intercrop systems is a driver for high land equivalent ratios, especially in systems combining a $\mathrm{C}_{3}$ and $\mathrm{C}_{4}$ species at sufficient levels of nitrogen. Better understanding how this enhanced light acquisition can be further optimized is possibly best done by a full orthogonal comparison of combinations of a $\mathrm{C}_{3}$ cereal, a $\mathrm{C}_{3}$ legume and a $\mathrm{C}_{4}$ cereal as this can address simultaneously the optimization of light acquisition and the role of nitrogen therein.

When yield at potential production levels is increased by intercropping as a result of a long growing season and high total light acquisition, acquisition of water and nutrients is likely to be increased proportionally to the increase in light acquisition that is achieved. Such an increase is neutral with respect to the conversion efficiencies of those resources, but it will lead to an increase in the acquisition efficiencies (cf. Fig. 3). Whether that is beneficial depends on the availability of those resources. When water is plentiful, such an increase is not a problem, but when water is not plentiful, the acquisition of extra water may be deemed problematic, even if per unit product (as demonstrated by values of WER $>1$ ) the water is used efficiently in intercrops (Mao et al., 2012).

When water resources are limiting, intercropping may help to use it efficiently in terms of grain per drop (Mao et al., 2012; Tan et al., 2020), but a water use efficient intercropping system may not be socially acceptable because use per unit area may be high, and competition between different users and uses intense (Hong, 2018). The question whether 
intercropping can contribute to a more efficient use of water depends on how the water is supplied (precipitation, irrigation) and on what would happen to the water if it were not used by the crop system. If the water would be lost through, e.g., deep percolation or evaporation and if it was not used by a crop system, then maximizing acquisition is not unsustainable. If, on the other hand, water needs to be supplied by irrigation, then sustainable use of the water may put a constraint on the acceptable amount of supply. Water use in intercropping may be reduced by choosing crops with lower water demands, as was done in Wuwei, China, in the 2000s when wheat/maize intercropping was replaced by pea/maize intercropping (Mao et al., 2012). Pea has much lower water demand than wheat, but it also has lower productivity in terms of grain per hectare. These examples on water use also highlight that very limited work has been done and no specific combinations could be mentioned as specifically optimal. Here the choice could best be led by what are important crops in drought prone areas where water is the major limiting resource.

When nitrogen resources are limiting, legumes are an obvious choice. Cereals perform better under low $\mathrm{N}$ growing conditions when they are grown in intercrops with legumes than as sole crops, because of relaxation of the competition for nitrogen. Legumes do not compete strongly for nitrogen with cereals, as a result of which cereal plants in intercrops with legumes have per plant more $\mathrm{N}$ available to them than cereal plants in monoculture. As there is already much research done on the principles that lead to the intercropping advantage in cereal-legume combinations through enhanced nitrogen acquisition, linking this known nitrogen related advantage to other resources like light, water or other nutrients seems the most interesting step forward for research.

When $\mathrm{P}$ or Fe are limiting, it will generally be advantageous to include a species in the intercrop that can make these nutrients more available. Such facilitation has been extensively documented in the literature. However, as noted by Brooker et al. (2015), the stress gradient hypothesis predicts that the importance of facilitation is greatest at adverse growing conditions, while competition will increase in importance when growing conditions are improved. Use of species with facilitative traits in intercropping may therefore have limited relevance for high yielding agriculture under good growing conditions. The potential for this type of facilitation seems specific to high $\mathrm{pH}$ soils. It may therefore be relevant to look at this aspect where soil $\mathrm{pH}$ is high and combine the $\mathrm{P}$ availability changes with studies on acquisition of other resources like nitrogen and light. So combinations that include legumes but also combinations of $\mathrm{C}_{3}$ and $\mathrm{C}_{4}$ species. 
In high yielding agriculture, pests, diseases and weeds are controlled by packages of methods (IPM: integrated pest management) in which the use of biocides is in practice rather a cornerstone than a means of last resort. However, consumers and intermediary actors in the value chain such as supermarkets are more and more demanding biocide free production. Intercropping helps to suppress pests, diseases and weeds naturally, and use of intercropping hence provides an opportunity to make agriculture less dependent on biocides. Zhang et al. (2019) show that on average intercropping reduces disease incidence in cereal-legume systems in Yunnan province, China, by 30\%. The worldwide overviews described in this review show that intercropping suppressed diseases in $79 \%$ of reported cases, pests in $68 \%$ and weeds in $86 \%$. Adding intercropping to the IPM package could make important advances possible to produce pesticide-free agricultural produce. Further quantitative analysis of the effect size is needed and envisaged in the EU Remix research program (www.remix-intercrops.eu).

The three vote counting analyses reported here by necessity relate to systems that have been studied and reported. In further meta-analyses it can be established whether there is reporting bias in favor of positive effects of intercropping (cf. Yu et al., 2015). A more fundamental bias is that effects on diseases and pests will have been studied only in cases where there were such problems. As can be seen from the number of studies on pests in legumes compared to cereals (Fig. 6), the frequency of insect studies does not represent the respective crop cultivation areas worldwide. And while weeds are present in all arable cropping systems the reported studies show much higher frequency of vegetables and legumes than would be expected based on their respective cultivation areas (Fig. 7). So, while the data convincingly indicate biotic stress problems and need for biocides can be reduced by using intercropping, the inverse is not true that in all cases intercropping will reduce biotic stresses. When host dilution is the major contributing factor for the effect of intercropping to pest or disease reduction the selection of crop combinations may not be very critical and could be made dependent on compatibility for, e.g., optimum resource use. Only when the effect is through very specific interactions this may provide design criteria. The relative importance of host dilution vs more specific mechanisms remains to be researched.

While seeking to understand the process of overyielding in relation to abiotic conditions it remains essential to keep interactions with biotic stresses in mind as agronomic optimal combinations are never defined by one single resource only. The quick vote counting analyses have shown that 
more often than not biotic stresses are reduced but there does not seem to be a literature that addresses the question how to combine advantages against biotic stresses with resource acquisition advantages.

\subsection{Further work is needed in many domains}

A lot of progress has been made in agricultural production over the past century through o.a. research nearly completely geared toward sole cropping. Despite this attention to improve sole cropping, the limited research on intercropping has shown large advantages that can address sustainability problems of current agro-ecosystems. If a comparable effort as put in sole cropping would be put into researching intercropping including breeding and mechanization much further gains can be expected.

First of all, empirical intercropping research is needed in western countries to build more familiarity with the opportunities and challenges of intercropping. This research should not be limited to already well-studied cereal/legume intercrops such as barley/pea, but should consider a wide set of crop species combinations, including highly productive intercrops of $\mathrm{C}_{3}$ and $\mathrm{C}_{4}$ cereals. Intercropping needs to be popularized, such that a broader complement of actors in society may engage in efforts to bring intercropping to practice. The role of intercropping in the development of eco-functional agriculture needs to be clarified and popularized.

Second, researchers need to work with farmers, advisers and industry to build workable intercropping solutions for practice in various settings. Multi-actor approaches need to be adopted to solve the problems that occur with mechanization and the use of yields from intercrops in the supply and processing chain.

Third, further in depth research is needed to explain how ratios for land or water equivalence are related to more common metrics for acquisition and conversion efficiency that have been developed in the analysis of sole crop production. This can help to convince conventional agronomists that intercropping has really something to offer for agriculture. Intercropping removes greater amount of nutrients from soils due to overyielding; however, it is very important to know how the soil fertility changes at longer time scales. Long-term studies are needed on soil fertility under intercropping, rotational cropping, and monocropping. In addition, land use studies are needed to clarify the potential contribution of intercropping to agricultural production, global resource use and food security. 
Fourth, modeling tools are needed to explore opportunities for intercropping under potential, water-limited, nutrient-limited, and otherwise stressed production conditions. Such models need to take account of the spatio-temporal complexity of intercrop systems. They can take the form of classical crop models with light or water partitioning modules (e.g., Gou et al., 2017b; Tan et al., 2020), or they could be detailed 3-D plant models modeling plant interactions at the organ level (e.g., Yu, 2016; Zhu et al., 2015). Such models may be used to analyze in more depth which factors are causal drivers of overyielding. They can elucidate under which conditions complementary light acquisition is the primary driver for overyielding, while increases in resource acquisition in the intercrop are merely a consequence of better light acquisition. They can alternatively elucidate under which conditions complementary acquisition of light is facilitated by complementary mechanisms for $\mathrm{N}$ acquisition. Such models can show the interplay between these resource acquisitions, where increased light acquisition can stimulate acquisition of water and nutrients, resulting in improved growth and further increases in light acquisition in a positive feedback cycle (Evers et al., 2019). Modeling is critically needed to better understand interactions in intercrops that evolve as a result of above-below ground interactions within intercropped plants (plant functioning and resource allocation) and between plants (competition and complementarity) over time during a growing season (Gaudio et al., 2019). Models can also help to understand how intercropping can help mitigate consequences of climate change.

Knowledge obtained in previous studies on intercropping should be synthesized in quantitative meta-analyses, to make the findings in the vast intercropping literature of thousands of papers better accessible. This review is just one step toward this synthesis. It has shown that some combinations are better studied than others and highlighted what could be good combinations for further work. Further meta-analyses will need useful and acceptable metrics to express intercrop performance in comparison to sole crops. Such metrics are needed not just in terms of per unit area productivity but also in relation to resource acquisition and conversion efficiencies and other indicators of system performance related to sustainability aspects of agriculture.

\section{Acknowledgments}

The authors acknowledge funding from the European Union's Horizon 2020 Program for Research and Innovation under grant agreement nº727217 (ReMIX: Redesigning European cropping systems based on species MIXtures) and from the National Key Research and Development Program of China (Project No.: 2016YFD0300202). 


\section{References}

Ae, N., Arihara, J., Okada, K., Yoshihara, T., Johansen, C., 1990. Phosphorus uptake by pigeon pea and its role in cropping systems of the Indian subcontinent. Science 248, 477-480.

Almasri, M.N., Kaluarachchi, J.J., 2004. Assessment and management of long-term nitrate pollution of ground water in agriculture-dominated watersheds. J. Hydrol. 295, 225-245.

Andersen, M.K., Hauggaard-Nielsen, H., Høgh-Jensen, H., Jensen, E.S., 2007. Competition for and utilisation of sulfur in sole and intercrops of pea and barley. Nutr. Cycl. Agroecosyst. 77, 143-153.

Anten, N., Hirose, T., 1999. Interspecific differences in above-ground growth patterns result in spatial and temporal partitioning of light among species in a tall-grass meadow. J. Ecol. $87,583-597$.

Anten, N., Hirose, T., 2003. Shoot structure, leaf physiology, and daily carbon gain of plant species in a tall grass meadow. J. Ecol. 84, 955-968.

Awal, M.A., Koshi, H., Ikeda, T., 2006. Radiation interception and use by maize/peanut intercrop canopy. Agric. For. Meteorol. 139, 74-83.

Baumann, D.T., Bastiaans, L., Kropff, M.J., 2004. Analysis and design of a leek-celery intercropping system using mechanistic and descriptive models. Acta Hortic. 638, 59-68.

Bedoussac, L., Justes, E., 2010. The efficiency of a durum wheat-winter pea intercrop to improve yield and wheat grain protein concentration depends on $\mathrm{N}$ availability during early growth. Plant Soil 330, 19-35.

Bedoussac, L., Justes, E., 2011. A comparison of commonly used indices for evaluating species interactions and intercrop efficiency: application to durum wheat-winter pea intercrops. Field Crop Res. 124, 25-36.

Bedoussac, L., Journet, E.P., Hauggaard-Nielsen, H., Naudin, C., Corre-Hellou, G., Jensen, E.S., Prieur, L., Justes, E., 2015. Ecological principles underlying the increase of productivity achieved by cereal-grain legume intercrops in organic farming. A review. Agron. Sustain. Dev. 35, 911-935.

Blaise, D., Bonde, A.N., Chaudhary, R.S., 2005. Nutrient uptake and balance of cotton + pigeonpea strip intercropping on rainfed Vertisols of central India. Nutr. Cycl. Agroecosyst. 73, 135-145.

Booth, M.S., Stark, J.M., Rastetter, E., 2005. Controls on nitrogen cycling in terrestrial ecosystems: a synthetic analysis of literature data. Ecol. Monogr. 75, 139-157.

Boudreau, M.A., 2013. Diseases in intercropping systems. Annu. Rev. Phytopathol. 51, 499-519.

Brooker, R.W., Maestre, F.T., Callaway, R.M., Lortie, C.L., Cavieres, L.A., Kunstler, G., Liancourt, P., Tielbörger, K., Travis, J.M.J., Anthelme, F., Armas, C., Coll, L., Corcket, E., Delzon, S., Forey, E., Kikvidze, Z., Olofsson, J., Pugnaire, F., Quiroz, C.L., Saccone, P., Schiffers, K., Seifan, M., Touzard, B., Michalet, R., 2008. Facilitation in plant communities: the past, the present and the future. J. Ecol. 96, 18-34.

Brooker, R.W., Bennett, A.E., Cong, W.F., Daniell, T.J., George, T.S., Hallett, P.D., Hawes, C., Iannetta, P.P.M., Jones, H.G., Karley, A.J., Li, L., McKenzie, B.M., Pakeman, R.J., Paterson, E., Schob, C., Shen, J., Squire, G., Watson, C.A., Zhang, C., Zhang, F., Zhang, J., White, P.J., 2015. Improving intercropping: a synthesis of research in agronomy, plant physiology and ecology. New Phytol. 206, 1107-1117.

Chalk, P.M., Peoples, M.B., McNeill, A.M., Boddey, R.M., Unkovich, M.J., Gardener, M.J., Silva, C.F., Chen, D., 2014. Methodologies for estimating nitrogen transfer between legume and companion species in agro-systems: a review of $15 \mathrm{~N}$ enriched techniques. Soil Biol. Biochem. 73, 10-21.

Chen, C., Wang, E., Yu, Q., 2010. Modelling the effects of climate variability and water management on crop water productivity and water balance in the North China Plain. Agric. Water Manag. 97, 1175-1184. 
Choudhary, V.K., Dixit, A., Chauhan, B.S., 2016. Resource-use maximisation through legume intercropping with maize in the eastern Himalayan region of India. Crop Pasture Sci. 67, 508-519.

Chowdhury, M.K., Rosario, E.L., 1994. Comparison of nitrogen, phosphorus and potassium utilization efficiency in maize/mungbean intercropping. J. Agric. Sci. 122, 193-199.

Coll, L., Cerrudo, A., Rizzalli, R., Monzon, J.P., Andrade, F.H., 2012. Capture and use of water and radiation in summer intercrops in the south-east Pampas of Argentina. Field Crop Res. 134, 105-113.

Cong, W.F., Ruijven, J., Mommer, L., De Deyn, G.B., Berendse, F., Hoffland, E., 2014. Plant species richness promotes soil carbon and nitrogen stocks in grasslands without legumes. J. Ecol. 102, 1163-1170.

Cong, W.F., Hoffland, E., Li, L., Janssen, B.H., van der Werf, W., 2015a. Intercropping affects the rate of decomposition of soil organic matter and root litter. Plant Soil 391, 399-411.

Cong, W.F., Hoffland, E., Li, L., Six, J., Sun, J.H., Bao, X.G., Zhang, F.S., van der Werf, W., 2015b. Intercropping enhances soil carbon and nitrogen. Glob. Chang. Biol. $21,1715-1726$.

Connolly, J., Goma, H.C., Rahim, K., 2001. The information content of indicators in intercropping research. Agric. Ecosyst. Environ. 87, 191-207.

Connor, D.J., Loomis, R.S., Cassman, K.G., 2011. Crop Ecology: Productivity and Management in Agricultural Systems. Cambridge University Press, New York, USA, p. 576.

Cooper, P.J.M., Gregory, P.J., Keatinge, J.D.H., Brown, S.C., 1987. Effects of fertilizer, variety and location on barley production under rainfed conditions in northern Syria 2. Soil-water dynamics and crop water use. Field Crop Res. 16, 67-84.

Corre-Hellou, G., Fustec, J., Crozat, Y., 2006. Interspecific competition for soil N and its interaction with N2 fixation, leaf expansion and crop growth in pea-barley intercrops. Plant Soil 282, 195-208.

Craufurd, P.Q., Wheeler, T.R., 2009. Climate change and the flowering time of annual crops. J. Exp. Bot. 60, 2529-2539.

Dhima, K.V., Lithourgidis, A.S., Vasilakoglou, I.B., Dordas, C.A., 2007. Competition indices of common vetch and cereal intercrops in two seeding ratio. Field Crop Res. 100, 249-256.

Dissanayaka, D.M.S.B., Maruyama, H., Masuda, G., Wasaki, J., 2015. Interspecific facilitation of $\mathrm{P}$ acquisition in intercropping of maize with white lupin in two contrasting soils as influenced by different rates and forms of P supply. Plant Soil 390, 223-236.

Döring, T.F., Knapp, S., Cohen, J.E., 2015. Taylor's power law and the stability of crop yields. Field Crop Res. 183, 294-302.

Dybzinski, R., Fargione, J.E., Zak, D.R., Fornara, D., Tilman, D., 2008. Soil fertility increases with plant species diversity in a long-term biodiversity experiment. Oecologia 158, 85-93.

El Dessougi, H., Dreele, A.Z., Claassen, N., 2003. Growth and phosphorus uptake of maize cultivated alone, in mixed culture with other crops or after incorporation of their residues. J. Plant Nutr. Soil Sci. 166, 254-261.

Evers, J.B., vander Werf, W., Stomph, T.J., Bastiaans, L., Anten, N.P.R., 2019. Understanding and optimizing species mixtures using functional-structural plant modelling. J. Exp. Bot. 70, 2381-2388. https://doi.org/10.1093/jxb/ery288.

Fan, F., Zhang, F., Song, Y., Sun, J., Bao, X., Guo, T., Li, L., 2006. Nitrogen fixation of faba bean (Vicia faba L.) interacting with a non-legume in two contrasting intercropping systems. Plant Soil 283, 275-286.

Fornara, D.A., Tilman, D., 2008. Plant functional composition influences rates of soil carbon and nitrogen accumulation. J. Ecol. 96, 314-322. 
Fujita, K., Ofosubudu, K.G., Ogata, S., 1992. Biological nitrogen fixation in mixed legumecereal cropping systems. Plant Soil 141, 155-175.

Gallagher, J.N., Biscoe, P.V., 1978. Radiation absorption, growth and yield of cereals. J. Agric. Sci. 91, 47-60.

Gao, Y., Duan, A., Sun, J., Li, F., Liu, Z., Liu, H., Liu, Z., 2009. Crop coefficient and wateruse efficiency of winter wheat/spring maize strip intercropping. Field Crop Res. $111,65-73$.

Gao, Y., Duan, A., Qiu, X., Sun, J., Zhang, J., Liu, H., Wang, H., 2010. Distribution and use efficiency of photosynthetically active radiation in strip intercropping of maize and soybean. Agron. J. 102, 1149-1157.

Gaudio, N., Escobar-Gutierez, A.J., Casadebaig, P., Evers, J.B., Gerard, F., Louarn, G., Colbach, N., Munz, S., Launay, M., Marrou, H., Barillot, R., Hinsinger, P., Bergez, J.-E., Combes, D., Durand, J.-L., Frak, E., Pages, L., Pradal, C., Saint-Jean, S., van der Werf, W., Justes, E., 2019. Current knowledge and future research opportunities for modeling annual crop mixtures. A review. Agron. Sustain. Dev. 39, 20. https://doi.org/10.1007/s13593-019-0562-6.

Ghanbari, A., Dahmardeh, M., Siahsar, B., Ramroudi, M., 2010. Effect of maize (Zea mays L.) — cowpea (Vigna unguiculata L.) intercropping on light distribution, soil temperature and soil moisture in arid environment. J. Food Agric. Environ. 8, 102-108.

Glowacka, A., 2013. Uptake of $\mathrm{Cu}, \mathrm{Zn}, \mathrm{Fe}$ and $\mathrm{Mn}$ by maize in the strip cropping system. Plant Soil Environ. 59, 322-328.

Gomez-Rodriguez, O., Zavaleta-Mejıa, E., Gonzalez-Hernandez, V.A., Livera-Munoz, M., Cardenas-Soriano, E., 2003. Allelopathy and microclimatic modification of intercropping with marigold on tomato early blight disease development. Field Crop Res. $83,27-34$.

Gooding, M.J., Kasynova, E., Ruske, R., Hauggaard-Nielsen, H., Jensen, E.S., Dahlmann, C., von Fragstein, P., Dibet, A., Corre Hellou, G., Crozat, Y., Pristeri, A., Romeo, M., Monti, M., Launay, M., 2007. Intercropping with pulses to concentrate nitrogen and sulphur in wheat. J. Agric. Sci. 145, 469-479.

Gou, F., van Ittersum, M.K., Simon, E., Leffelaar, P.A., van der Putten, P.E.L., Zhang, L., van der Werf, W., 2017a. Intercropping wheat and maize increases total radiation interception and wheat RUE but lowers maize RUE. Eur. J. Agron. 84, 125-139.

Gou, F., van Ittersum, M.K., van der Werf, W., 2017b. Simulating potential growth in a relay-strip intercropping system: model description, calibration and testing. Field Crop Res. 200, 122-142.

Gou, F., van Ittersum, M.K., Couëdel, A., Zhang, Y., Wang, Y., van der Putten, P.E.L., Zhang, L., van der Werf, W., 2018. Intercropping with wheat lowers nutrient uptake and biomass accumulation of maize, but increases photosynthetic rate of the ear leaf. AoB Plants 10, ply010. https://doi.org/10.1093/aobpla/ply010.

Graham, R.D., Welch, R.M., Saunders, D.A., Ortiz-Monasterio, I., Bouis, H.E., Boniebale, M., de Haan, S., Burgos, G., Thiele, G., Liria, R., Meisner, C.A., Neene, S.E., Potts, M.J., Kadian, M., Hobbs, P.R., Gupta, R.K., Twomlow, W., 2007. Nutritious subsistence food systems. Adv. Agron. 92, 1-74. https://doi.org/ 10.1016/S0065-2113(04)92001-9.

Hao, W.Y., Ren, L.X., Ran, W., Shen, Q.R., 2010. Allelopathic effects of root exudates from watermelon and rice plants on Fusarium oxysporum f.sp. niveum. Plant Soil 336, 485-497.

Hassan, H.M., Marschner, P., McNeill, A., Tang, C., 2012. Growth, P uptake in grain legumes and changes in rhizosphere soil $\mathrm{P}$ pools. Biol. Fertil. Soils 48, 151-159.

Haugaard-Nielsen, H., Jornsgaard, B., Kinane, J., Jensen, E.S., 2008. Grain legume-cereal intercropping: the practical application of diversity, competition and facilitation in arable and organic cropping systems. Renewable Agric. Food Syst. 23, 3-12. 
Hauggaard-Nielsen, H., Ambus, P., Jensen, E.S., 2001a. Temporal and spatial distribution of roots and competition for nitrogen in pea-barley intercrops - a field study employing P-32 technique. Plant Soil 236, 63-74.

Hauggaard-Nielsen, H., Ambus, P., Jensen, E.S., 2001b. Interspecific competition, $\mathrm{N}$ use and interference with weeds in pea-barley intercropping. Field Crop Res. 70, 101-109.

Hauggaard-Nielsen, H., Ambus, P., Jensen, E.S., 2003. The comparison of nitrogen use and leaching in sole cropped versus intercropped pea and barley. Nutr. Cycl. Agroecosyst. 65, 289-300.

Hinsinger, P., 2001. Bioavailability of soil inorganic P in the rhizosphere as affected by root-induced chemical changes: a review. Plant Soil 237, 173-195.

Hinsinger, P., Plassard, C., Tang, C.X., Jaillard, B., 2003. Origins of root-mediated pH changes in the rhizosphere and their responses to environmental constraints: a review. Plant Soil 248, 43-59.

Hinsinger, P., Betencourt, E., Bernard, L., Brauman, A., Plassard, C., Shen, J., Zhang, F., 2011. P for two, sharing a scarce resource: soil phosphorus acquisition in the rhizosphere of intercropped species. Plant Physiol. 156, 1078-1086.

Holzworth, D.P., Huth, N.I., de Voil, P.G., Zurcher, E.J., Herrmann, N.I., Mclean, G., Chenu, K., van Oosterom, E.J., Snow, V., Murphy, C., Moore, A.D., Brown, H., Whish, J.P.M., Verrall, S., Fainges, J., Bell, L.W., Peake, A.S., Poulton, P.L., Hochman, Z., Thorburn, P.J., Gaydon, D.S., Dalgliesh, N.P., Rodriguez, D., Cox, H., Chapman, S., Doherty, A., Teixeira, E., Sharp, J., Cichota, R., Vogeler, I., Li, F.Y., Wang, E., Hammer, G.L., Robertson, M.J., Dims, J.P., Whitbread, A.M., Hunt, J., van Rees, H., McClelland, T., Carberry, P.S., Hargreaves, J.N.G., Mac Leod, N., McDonald, C., Harsdorf, J., Wedgwood, S., Keating, B.A., 2014. APSIM-evolution towards a new generation of agricultural systems simulation. Environ. Model. Software 62, 327-350.

Hong, Y., 2018. Does Intercropping Have a Future in China?-Insights from a Case Study in Gansu Province. Doctoral thesis, Wageningen University, Wageningen, The Netherlands.

Horst, W.J., Waschkies, C., 1987. Phosphorus-nutrition of spring wheat (Triticum aestivum L) in mixed culture with white lupin (Lupinus albus L). J. Plant Nutr. Soil Sci. $150,1-8$.

Howden, S., Meinke, H., Power, B., McKeon, G., 2003. Risk Management of Wheat in a Non-Stationary Climate: Frost in Central Queensland. International Congress on Modelling and Simulation, pp. 17-22.

Hu, F., Zhao, C., Feng, F., Chai, Q., Mu, Y., Zhang, Y., 2017. Improving N management through intercropping alleviates the inhibitory effect of mineral $\mathrm{N}$ on nodulation in pea. Plant Soil 412, 235-251.

Iannetta, P.P.M., Begg, G., James, E.K., Smith, B., Davies, C., Karley, A., Lopez Del Egido, L., Hawes, C., Young, M., Ramsay, G., et al., 2013. Sustainable intensification: a pivotal role for legume supported crop systems. Asp. Appl. Biol. 121, 73-82.

Inal, A., Gunes, A., Zhang, F., Cakmak, I., 2007. Peanut/maize intercropping induced changes in rhizosphere and nutrient concentrations in shoots. Plant Physiol. Biochem. $45,350-356$.

IPCC Climate Change, 2007. The physical science basis. In: Solomon, S., Qin, D., Manning, M., Chen, Z., Marquis, M., Averyt, K.B., Tignor, M., Miller, H.L. (Eds.), Contribution of Working Group I to the Fourth Assessment Report of the Intergovernmental Panel on Climate Change. Cambridge University Press, Cambridge, p. 996.

Jensen, E.S., 1996. Grain yield, symbiotic $\mathrm{N}_{2}$ fixation and interspecific competition for inorganic $\mathrm{N}$ in pea-barley intercrops. Plant Soil 182, 25-38. 
Johansen, A., Jensen, E.S., 1996. Transfer of $\mathrm{N}$ and P from intact or decomposing roots of pea to barley interconnected by an arbuscular mycorrhizal fungus. Soil Biol. Biochem. 28, 73-81.

Kamal, K., Hagagg, L., Awad, F., 2000. Improved Fe and Zn acquisition by guava seedlings grown in calcareous soils intercropped with graminaceous species. J. Plant Nutr. 23, 2071-2080.

Keating, B., Carberry, P., 1993. Resource capture and use in intercropping: solar radiation. Field Crop Res. 34, 273-301.

Keating, B.A., Carberry, P.S., Hammer, G.L., Probert, M.E., Robertson, M.J., Holzworth, D., Huth, N.I., Hargreaves, J.N.G., Meinke, H., Hochman, Z., McLean, G., Verburg, K., Snow, V., Dimes, J.P., Silburn, M., Wang, E., Brown, S., Bristow, K.L., Asseng, S., Chapman, S., McCown, R.L., Freebairn, D.M., Smith, C.J., 2003. An overview of APSIM, a model designed for farming systems simulation. Eur. J. Agron. 18, 267-288.

Knudsen, M.T., Hauggaard-Nielsen, H., Jørnsgard, B., Jensen, E.S., 2004. Comparison of interspecific competition and $\mathrm{N}$ use in pea-barley, faba bean-barley and lupin-barley intercrops grown at two temperate locations. J. Agric. Sci. 142, 617-627.

Koricheva, J., Gurevitch, J., Mengersen, K., 2012. Handbook of Meta-Analysis in Ecology and Evolution. Princeton University Press. 498 pp.

Kropff, M.J., Goudriaan, J., 1994. Competition for resource capture in agricultural crops. In: Kropff, M.J., Goudriaan, J. (Eds.), Resource Capture by Crops. Nottingham University Press, pp. 233-253.

Kutman, U.B., Yildiz, B., Cakmak, I., 2011. Effect of nitrogen on uptake, remobilization and partitioning of zinc and iron throughout the development of durum wheat. Plant Soil 342, 149-164.

Letourneau, D.K., Armbrecht, I., Rivera, B.S., Lerma, J.M., Carmona, E.J., Daza, M.C., Escobar, S., Galindo, V., Gutiérrez, C., López, S.D., Mejía, J.L., Acosta Rangel, A.M., Rangel, J.H., Rivera, L., Saavedra, C.A., Torres, A.M., Trujillo, A.R., 2011. Does plant diversity benefit agroecosystems? A synthetic review. Ecol. Appl. 21, 9-21.

Li, L., Yang, S., Li, X., Zhang, F., Christie, P., 1999. Interspecific complementary and competitive interactions between intercropped maize and faba bean. Plant Soil 212, 105-114.

Li, L., Sun, J.H., Zhang, F.S., Li, X.L., Yang, S.C., Rengel, Z., 2001. Wheat/maize or wheat/soybean strip intercropping: I. Yield advantage and interspecific interactions on nutrients. Field Crop Res. 71, 123-137.

Li, L., Tang, C., Rengel, Z., Zhang, F., 2003. Chickpea facilitates phosphorus uptake by intercropped wheat from an organic phosphorus source. Plant Soil 248, 297-303.

Li, S., Li, L., Zhang, F., Tang, C., 2004. Acid phosphatase role in chickpea/maize intercropping. Ann. Bot. 94, 297-303.

Li, W., Li, L., Sun, J., Guo, T., Zhang, F., Bao, X., Peng, A., Tang, C., 2005. Effects of intercropping and nitrogen application on nitrate present in the profile of an Orthic Anthrosol in Northwest China. Agric. Ecosyst. Environ. 105, 483-491.

Li, L., Sun, J.H., Zhang, F.S., Guo, T.W., Bao, X.G., Smith, F.A., Smith, S.E., 2006. Root distribution and interactions between intercropped species. Oecologia 147, 280-290.

Li, L., Li, S.M., Sun, J.H., Zhou, L.L., Bao, X.G., Zhang, H.G., Zhang, F.S., 2007. Diversity enhances agricultural productivity via rhizosphere phosphorus facilitation on phosphorus-deficient soils. Proc. Natl. Acad. Sci. U. S. A. 104, 11192-11196.

Li, Y.-Y., Yu, C.-B., Cheng, X., Li, C.-J., Sun, J.-H., Zhang, F.-S., Lambers, H., Li, L., 2009. Intercropping alleviates the inhibitory effect of $\mathbf{N}$ fertilization on nodulation and symbiotic $\mathrm{N}_{2}$ fixation of faba bean. Plant Soil 323, 295-308.

Li, L., Sun, J., Zhang, F., 2011. Intercropping with wheat leads to greater root weight density and larger below-ground space of irrigated maize at late growth stages. Soil Sci. Plant Nutr. 57, 61-67. 
Li, L., Zhang, L.Z., Zhang, F.S., 2013. Crop mixtures and the mechanisms of overyielding. In: Levin, S.A. (Ed.), Encyclopedia of Biodiversity, second ed. In: vol. 2. Academic Press, Waltham, MA, pp. 382-395.

Li, L., Tilman, D., Lambers, H., Zhang, F.S., 2014. Plant diversity and overyielding: insights from belowground facilitation of intercropping in agriculture. New Phytol. 203, 63-69.

Li, B., Li, Y.-Y., Wu, H.-M., Zhang, F.-F., Li, C.-J., Li, X.-X., Lambers, H., Li, L., 2016. Root exudates drive interspecific facilitation by enhancing nodulation and $\mathrm{N}_{2}$ fixation. Proc. Natl. Acad. Sci. U. S. A. 113, 6496-6501.

Li, X.G., de Boer, W., Zhang, Y.A., Ding, C.F., Zhang, T.L., Wang, X.X., 2018. Suppression of soil-borne Fusarium pathogens of peanut by intercropping with the medicinal herb Atractylodes lancea. Soil Biol. Biochem. 116, 120-130.

Liebman, M., Dyck, E., 1993. Crop-rotation and intercropping strategies for weed management. Ecol. Appl. 3, 92-122.

Lithourgidis, A.S., Dordas, C.A., Damalas, C.A., Vlachostergios, D.N., 2011. Annual intercrops: an alternative pathway for sustainable agriculture. Aust. J. Crop Sci. 5, 396-410.

Mahallati, M.N., Koocheki, A., Mondani, F., Feizi, H., Amirmoradi, S., 2015. Determination of optimal strip width in strip intercropping of maize (Zea mays L.) and bean (Phaseolus vulgaris L.) in Northeast Iran. J. Clean. Prod. 106, 343-350.

Mao, L.L., Zhang, L.Z., Li, W.Q., van der Werf, W., Sun, J.H., Spiertz, H., Li, L., 2012. Yield advantage and water saving in maize/pea intercrop. Field Crop Res. 138, 11-20.

Mao, L.L., Zhang, L.Z., Evers, J.B., Heinke, M., van der Werf, W., Liu, S.D., Zhang, S.P., Zhao, X.H., Wang, B.M., Li, Z.H., 2016. Identification of plant configurations maximizing radiation capture in relay strip cotton using a functional structural plant model. Field Crop Res. 187, 1-11.

Marschner, H., 2011. Mineral Nutrition of Higher Plants, third ed. Academic Press.

Marshall, B., Willey, R.W., 1983. Radiation interception and growth in an intercrop of pearl millet/groundnut. Field Crop Res. 7, 141-160.

Martin-Guay, M.O., Pauette, A., Dupras, J., Rivest, D., 2018. The new green revolution: sustainable intensification of agriculture by intercropping. Sci. Total Environ. 615, 767-772.

Matthews, R.B., Azamali, S.N., Saffell, R.A., Peacock, J.M., Williams, J.H., 1991. Plant growth and development in relation to the microclimate of a sorghum groundnut intercrop. Agric. For. Meteorol. 53, 285-301.

Mead, R., Willey, R.W., 1980. The concept of a 'land equivalent ratio' and advantages in yields from intercropping. Exp. Agric. 16, 217-228.

Meinke, H., Stone, R.C., 2005. Seasonal and inter-annual climate forecasting: the new tool for increasing preparedness to climate variability and change in agricultural planning and operations. Clim. Change 70, 221-253.

Meinke, H., Nelson, R., Kokic, P., Stone, R., Selvaraju, R., Baethgen, W., 2006. Actionable climate knowledge-from analysis to synthesis. Climate Res. 33, 101-110.

Miao, Q., Rosa, R.D., Shi, H., Paredes, P., Zhu, L., Dai, J., Gonçalves, J.M., Pereira, L.S., 2016. Modeling water use, transpiration and soil evaporation of spring wheat-maize and spring wheat-sunflower relay intercropping using the dual crop coefficient approach. Agric. Water Manag. 165, 211-229.

Miyazawa, K., Murakami, T., Takeda, M., Murayama, T., 2010. Intercropping green manure crops-effects on rooting patterns. Plant Soil 331, 231-239.

Mondal, S.S., Sarkar, S., Pramanik, C.K., 2004. Effect of K on soil fertility and productivity under intercropped soya bean (Glycine max L. Merrill) and sesame (Sesamum indicum L.). Trop. Agric. 81, 66-72.

Monteith, J.L., 1977. Climate and efficiency of crop production in Britain. Philos. Trans. R. Soc. London, Ser. B 281, 277-294. 
Morris, R.A., Garrity, D.P., 1993a. Resource capture and utilization in intercropping: water. Field Crop Res. 34, 303-317.

Morris, R.A., Garrity, D.P., 1993b. Resource capture and utilization in intercropping; non-nitrogen nutrients. Field Crop Res. 34, 319-334.

Naudin, C., Corre-Hellou, G., Pineau, S., Crozat, Y., Jeuffroy, M.H., 2010. The effect of various dynamics of $\mathrm{N}$ availability on winter pea-wheat intercrops: crop growth, $\mathrm{N}$ partitioning and symbiotic $\mathrm{N}_{2}$ fixation. Field Crop Res. 119, 2-11.

Nelson, R., Kokic, P., Meinke, H., 2007. From rainfall to farm incomes-transforming advice for Australian drought policy: part II-forecasting farm incomes. Aust. J. Agric. Res. $58,1004-1012$.

Ofosu-Anim, J., Limbani, N.V., 2007. Effect of intercropping on the growth and yield of cucumber (Cucumis sativus L.) and okra (Abelmoschus esculentus L. Moench). Int. J. Agric. Biol. 9, 594-597.

Pappa, V.A., Rees, R.M., Walker, R.L., Baddeley, J.A., Watson, C.A., 2011. Nitrous oxide emissions and nitrate leaching in an arable rotation resulting from the presence of an intercrop. Agric. Ecosyst. Environ. 141, 153-161.

Pearse, S.J., Veneklaas, E.J., Cawthray, G.R., Bolland, M.D.A., Lambers, H., 2006. Carboxylate release of wheat, canola and 11 grain legume species as affected by phosphorus status. Plant Soil 288, 127-139.

Pelzer, E., Hombert, N., Jeuffroy, M.H., Makowski, D., 2014. Meta-analysis of the effect of nitrogen fertilization on annual cereal-legume intercrop production. Agron. J. 106, 1775-1786. https://doi.org/10.2134/agronj13.0590.

Postma, J.A., Kuppe, C., Owen, M.R., Mellor, N., Griffiths, M., Bennett, M.J., Lynch, J.P., Watt, M., 2017. OPENSIMROOT: widening the scope and application of root architectural models. New Phytol. 215, 1274-1286. https://doi.org/10.1111/nph.14641.

Qin, J.H., He, H.Z., Luo, S.M., Li, H.S., 2013. Effects of rice-water chestnut intercropping on rice sheath blight and rice blast diseases. Crop Prot. 43, 89-93.

Rao, M.R., Willey, R.W., 1980. Evaluation of yield stability in intercropping: studies on sorghum/pigeonpea. Exp. Agric. 16, 105-116.

Raseduzzaman, M.D., Jensen, E.S., 2017. Does intercropping enhance yield stability in arable crop production? A meta-analysis. Eur. J. Agron. 91, 25-33.

Ricord, M., 2018. Evaluating Intercropping Systems as a Sustainable Agroecosystem Alternative to Reduce Greenhouse Gas Emissions. Master thesis, University of Waterloo.

Rosa, R.D., Paredes, P., Rodrigues, G.C., Alves, I., Fernando, R.M., Pereira, L.S., Allen, R.G., 2012. Implementing the dual crop coefficient approach in interactive software. 1. Background and computational strategy. Agric. Water Manag. 103, 8-24.

Rusinamhodzi, L., Corbeels, M., Nyamangara, J., Giller, K.E., 2012. Maize-grain legume intercropping is an attractive option for ecological intensification that reduces climatic risk for smallholder farmers in central Mozambique. Field Crop Res. 136, 12-22.

Russell, G., Jarvis, P.G., Monteith, J.L., 1989. Absorption of radiation by canopies and stand growth. In: Russell, G. (Ed.), Plant Canopy: Their Growth, Form and Function. Cambridge University Press, Cambridge, pp. 21-39.

Salvagiotti, F., Cassman, K.G., Specht, J.E., Walters, D.T., Weiss, A., Dobermann, A., 2008. Nitrogen uptake, fixation and response to fertilizer $\mathrm{N}$ in soybeans: a review. Field Crop Res. 108, 1-13.

Schoeny, A., Lemarchand, E., Tivoli, B., Jumel, S., Rouault, F., 2010. Effect and underlying mechanisms of pea-cereal intercropping on the epidemic development of Ascochyta blight. Eur. J. Plant Pathol. 126, 317-331.

Singh, R.J., Ahlawat, I.P.S., 2012. Dry matter, nitrogen, phosphorous, and potassium partitioning, accumulation, and use efficiency in transgenic cotton-based cropping systems. Commun. Soil Sci. Plant Anal. 43, 2633-2650. 
Szumigalski, A.R., Van Acker, R.C., 2006. Nitrogen yield and land use efficiency in annual sole crops and intercrops. Agron. J. 98, 1030-1040.

Szumigalski, A.R., Van Acker, R.C., 2008. Land equivalent ratios, light interception, and water use in annual intercrops in the presence or absence of in-crop herbicides. Agron. J. 100, 1145-1154.

Tan, M.X., Gou, F., Stomph, T.J., Wang, J., Yin, W., Zhang, L.Z., Chai, Q., Van der Werf, W., 2020. Dynamic process-based modelling of crop growth and competitive water extraction in relay strip intercropping: model development and application to wheatmaize intercropping. Field Crop Res. https://doi.org/10.1016/j.fcr.2019.107613.

Tang, X., Bernard, L., Brauman, A., Daufresne, T., Deleporte, P., Desclaux, D., Souche, G., Placella, S.A., Hinsinger, P., 2014. Increase in microbial biomass and phosphorus availability in the rhizosphere of intercropped cereal and legumes under field conditions. Soil Biol. Biochem. 75, 86-93.

Thilakarathna, M.S., McElroy, M.S., Chapagain, T., Papadopoulos, Y.A., Raizada, M.N., 2016. Belowground nitrogen transfer from legumes to non-legumes under managed herbaceous cropping systems. A review. Agron. Sustain. Dev. 36, 58.

Tilman, D., Knops, J., Wedin, D., Reich, P., Ritchie, M., Siemann, E., 1997. The influence of functional diversity and composition on ecosystem processes. Science 277, 1300-1302.

Tofinga, M., Paolini, R., Snaydon, R., 1993. A study of root and shoot interactions between cereals and peas in mixtures. J. Agric. Sci. 120, 13-24.

Trachel, S., Keappler, S.M., Brown, K.M., Lynch, J.P., 2011. Shovelomic: high throughput phenotyping of maize (Zea mays L.) root architecture in the field. Plant Soil 341, 75-87.

Trenbath, B., 1986. Resource use by intercrops. In: Francis, C.A. (Ed.), Multiple Cropping Systems. Macmillan, New York, pp. 57-81.

Twomlow, S., Mugabe, F.T., Mwale, M., Delve, R., Nanja, D., Carberry, P., Howden, M., 2008. Building adaptive capacity to cope with increasing vulnerability due to climatic change in Africa - a new approach. Phys. Chem. Earth. 33, 780-787.

Valkama, E., Lemola, R., Känkänen, H., Turtola, E., 2015. Meta-analysis of the effects of undersown catch crops on nitrogen leaching loss and grain yields in the Nordic countries. Agric. Ecosyst. Environ. 203, 93-101.

van Ittersum, M.K., Rabbinge, R., 1997. Concepts in production ecology for analysis and quantification of agricultural input-output combinations. Field Crop Res. 52, 197-208.

van Keulen, H., 1982. Graphical analysis of annual crop response to fertiliser application. Agr. Syst. 9, 113-126.

van Oort, P., Gou, F., Stomph, T.J., van der Werf, W., 2020. Effects of strip width on yields in relay-strip intercropping: a simulation study. Eur. J. Agron. 112. https://doi.org/ 10.1016/j.eja.2019.125936.

Vance, C.P., Uhde-Stone, C., Allan, D.L., 2003. Phosphorus acquisition and use: critical adaptations by plants for securing a nonrenewable resource. New Phytol. 157, 423-447.

Vandermeer, J., 1989. The Ecology of Intercropping. Cambridge University Press. 237 pp.

Viguier, L., Bedoussac, L., Journet, E.P., Justes, E., 2018. Yield gap analysis extended to marketable grain reveals the profitability of organic lentil-spring wheat intercrops. Agron. Sustain. Dev. 38, 39. https://doi.org/10.1007/s13593-018-0515-5.

von Arx, G., Graf Pannatier, E., Thimonier, A., Rebetez, M., 2013. Microclimate in forests with varying leaf area index and soil moisture: potential implications for seedling establishment in a changing climate. J. Ecol. 101, 1201-1213.

Walker, S., Ogindo, H.O., 2003. The water budget of rainfed maize and bean intercrop. Phys. Chem. Earth. 28, 919-926.

Wallach, D., Makowski, D., Jones, J.W., Brun, F., 2014. Working with Dynamic Crop Models. Academic Press, New York. 487 pp. 
Wang, X.C., Yang, W.Y., Ren, W.J., Deng, X.Y., Zhang, Q., Xiang, D.B., Yong, T.W., 2012. Study on yield and differences of nutrient absorptions of maize in wheat/maize/ soybean and wheat/maize/sweet potato relay intercropping systems. Plant nutrition and fertilizer. Science 18, 803-812.

Wang, Z.G., Jin, X., Bao, X.G., Li, X.F., Zhao, J.H., Sun, J.H., Christie, P., Li, L., 2014. Intercropping enhances productivity and maintains most soil fertility properties relative to sole cropping. PLoS One 9, e113984.

Wang, Z., Zhao, X., Wu, P., He, J., Chen, X., Gao, Y., Cao, X.C., 2015a. Radiation interception and utilization by wheat/maize strip intercropping systems. Agric. For. Meteorol. 204, 58-66.

Wang, Z.G., Bao, X.G., Li, X.F., Jin, X., Zhao, J.H., Sun, J.H., Christie, P., Li, L., 2015 b. Intercropping maintains soil fertility in terms of chemical properties and enzyme activities on a timescale of one decade. Plant Soil 391, 265-282.

Willey, R.W., 1990. Resource use in intercropping systems. Agric. Water Manag. 17, 215-231.

Xia, H.Y., Wang, Z.G., Zhao, J.H., Sun, J.H., Bao, X.G., Christie, P., Zhang, F.S., Li, L., 2013a. Contribution of interspecific interactions and phosphorus application to sustainable and productive intercropping systems. Field Crop Res. 154, 53-64.

Xia, H.Y., Zhao, J.H., Sun, J.H., Xue, Y.F., Eagling, T., Bao, X.G., Zhang, F.S., Li, L., 2013b. Maize grain concentrations and above-ground shoot acquisition of micronutrients as affected by intercropping with turnip, faba bean, chickpea, and soybean. Sci. China Life Sci. 56, 823-834.

Xue, Y.F., Xia, H.Y., Christie, P., Zhang, Z., Li, L., Tang, C.X., 2016. Crop acquisition of phosphorus, iron and zinc from soil in cereal/legume intercropping systems: a critical review. Ann. Bot. 117, 363-377.

Yang, C., Huang, G., Chai, Q., Luo, Z., 2011. Water use and yield of wheat/maize intercropping under alternate irrigation in the oasis field of northwest China. Field Crop Res. 124, 426-432.

Yang, M., Zhang, Y., Qi, L., Mei, X.Y., Liao, J.J., Ding, X.P., Deng, W.P., Fan, L.M., He, X.H., Vivanco, J.M., 2014. Plant-plant-microbe mechanisms involved in soil-borne disease suppression on a maize and pepper intercropping system. PLoS One 9 (12), e115052. https://doi.org/10.1371/journal.pone.0115052.

Yang, X., Tian, Z., Sun, L., Chen, B., Tubiello, F.N., Xu, Y., 2017. The impacts of increased heat stress events on wheat yield under climate change in China. Clim. Change 140, 605-620.

Yin, X., Olesen, J.E., Wang, M., Öztürk, I., Zhang, H., Chen, F., 2016. Impacts and adaptation of the cropping systems to climate change in the Northeast Farming Region of China. Eur. J. Agron. 78, 60-72.

Yong, T.W., Yang, W.Y., Xiang, D.B., Chen, X.R., Wan, Y., 2012. Production and $\mathrm{N}$ nutrient performance of wheat-maize-soybean relay strip intercropping system and evaluation of interspecies competition. Acta Pratacul. Sin. 38, 333-343.

Yu, Y., 2016. Crop Yields in Intercropping: Meta-Analysis and Virtual Plant Modelling. Doctoral thesis, Wageningen University, Wageningen, The Netherlands.

Yu, Y., Stomph, T.-J., Makowski, D., van der Werf, W., 2015. Temporal niche differentiation increases the land equivalent ratio of annual intercrops: a meta-analysis. Field Crop Res. 184, 133-144.

Yu, Y., Makowski, D., Stomph, T.J., Van der Werf, W., 2016a. Robust increases of land equivalent ratio with temporal niche differentiation: a meta-quantile regression. Agron. J. 108, 2269-2279. https://doi.org/10.2134/agronj2016.03.0170.

Yu, Y., Stomph, T.J., Makowski, D., Zhang, L., Van der Werf, W., 2016b. A meta-analysis of relative crop yields in cereal/legume mixtures suggests options for management. Field Crop Res. 198, 269-279. https://doi.org/10.1016/j.fcr.2016.08.001. 
Zhang, F., Li, L., 2003. Using competitive and facilitative interactions in intercropping systems enhances crop productivity and nutrient-use efficiency. Plant Soil 248, 305-312.

Zhang, L., van der Werf, W., Zhang, S., Li, B., Spiertz, J.H.J., 2007. Growth, yield and quality of wheat and cotton in relay strip intercropping systems. Field Crop Res. 103, 178-188.

Zhang, L., van der Werf, W., Bastiaans, L., Zhang, S., Li, B., Spiertz, J.H.J., 2008. Light interception and utilization in relay intercrops of wheat and cotton. Field Crop Res. 107, 29-42.

Zhang, W.-P., Liu, G.-C., Sun, J.-H., Fornara, D., Zhang, L.-Z., Zhang, F.-F., Li, L., 2017. Temporal dynamics of nutrient uptake by neighbouring plant species: evidence from intercropping. Funct. Ecol. 31, 469-479.

Zhang, C.C., Dong, Y., Tang, L., Zheng, Y., Makowski, D., Yu, Y., Zhang, F.S., Vander Werf, W., 2019. Intercropping cereals with faba bean reduces plant disease incidence regardless of fertilizer input; a meta-analysis. Eur. J. Plant Pathol. 154, 931-942.

Zhu, Y.Y., Fang, H., Wang, Y.Y., Fan, J.X., Yang, S.S., Mew, T.W., Mundt, C.C., 2005. Panicle blast and campy moisture in rice cultivar mixtures. Ecol. Epidemiol. 95, 433-438.

Zhu, J., van der Werf, W., Anten, N.P.R., Vos, J., Evers, J.B., 2015. The contribution of phenotypic plasticity to complementary light capture in plant mixtures. New Phytol. 207, 1213-1222.

Zhu, J., van der Werf, W., Vos, J., Anten, N.P.R., van der Putten, P.E.L., Evers, J.B., 2016. High productivity of wheat intercropped with maize is associated with plant architectural responses. Ann. Appl. Biol. 168, 357-372.

Zuo, Y.M., Zhang, F.S., 2007. Effect of peanut mixed cropping with gramineous species on micronutrient concentrations and iron chlorosis of peanut plants grown in a calcareous soil. Plant Soil 306, 23-36.

Zuo, Y.M., Zhang, F.S., Li, X.L., Cao, Y.P., 2000. Studies on the improvement in iron nutrition of peanut by intercropping with maize on a calcareous soil. Plant Soil 220, 13-25.

Zuo, Y.M., Li, X.L., Cao, Y.P., Zhang, F.S., Christie, P., 2003. Iron nutrition of peanut enhanced by mixed cropping with maize: possible role of root morphology and rhizosphere microflora. J. Plant Nutr. 26, 2093-2110. 